\title{
Foraminiferal and palynological organic matter records of the Upper Badenian (Middle Miocene) deposits at Anadoly (marginal part of the Ukrainian Carpathian Foredeep Basin)
}

\author{
Przemysław GEDL ${ }^{1, *}$, Danuta PERYT ${ }^{2}$ and Tadeusz Marek PERYT ${ }^{3}$ \\ 1 Polish Academy of Sciences, Institute of Geological Sciences, Research Centre in Kraków, Senacka 1, 31-002 Kraków, Poland \\ 2 Polish Academy of Sciences, Institute of Paleobiology, Twarda 51/55, 00-818 Warszawa, Poland \\ 3 Polish Geological Institute - National Research Institute, Rakowiecka 4, 00-975 Warszawa, Poland
}

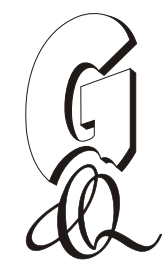

Gedl, P., Peryt, D., Peryt, T.M., 2016. Foraminiferal and palynological organic matter records of the Upper Badenian (Middle Miocene) deposits at Anadoly (marginal part of the Ukrainian Carpathian Foredeep Basin). Geological Quarterly, 60 (2): 517-536, doi 10.7306/gq.1300

The Badenian section of Anadoly near Kamyanets Podilskyy (Ukrainian Carpathian Foredeep Basin) consists of the Tyras $\mathrm{Fm}$. (gypsum and Ratyn Limestone) and the Ternopil Mb. of the Kosiv Fm. The latter are $5.3 \mathrm{~m}$ thick and are composed of dark grey mudstones with limestone intercalations. This study indicates the occurrence of over 54 species of benthic foraminifers and 10 species of planktonics. Benthic foraminifera are represented mainly by calcareous forms; agglutinated tests are very rare. Planktonic foraminifera appear in the upper part of the succession studied. Five benthic foraminiferal assemblages are recognized: A (Elphidium/Lobatula/Astrononion) B (Hauerinidae), C (Cibicidoides/Lobatula), D (Porosononion) and $\mathrm{E}$ (Uvigerina/Bulimina). The foraminiferal record indicates deposition in a shallow subtidal environment $(20 \mathrm{~m}$ depth) of normal marine salinity and temperate waters followed by gradual deepening of the basin to $>50 \mathrm{~m}$. Analysis of foraminiferal assemblages indicates that bottom waters were highly oxygenated during deposition of the lower and middle parts of the Anadoly sequence. During deposition of the upper part of the sequence the oxygenation of bottom water gradually decreased, as expressed by a large decrease in the proportion of oxic species and an increase in dysoxic ones. The same set of samples yielded low amounts of palynological organic matter represented by dominant black opaque phytoclasts; bisaccate pollen grains and dinoflagellate cysts are rare. Taxonomically impoverished assemblages of the latter consist of dominant Polysphaeridium and Cleistosphaeridium placacanthum associated with Lingulodinium machaerophorum and a few other taxa. The taxonomically richest assemblage was found in the topmost sample. These changes were interpreted as indicative for increased salinity in the surface water layer, with its maximum in the middle part of the section; the assemblage from the topmost part is characteristic for normal marine salinity.

Keywords: Paratethys, Carpathian Foredeep, Upper Badenian, foraminifers, dinoflagellate cysts, palaeoenvironment.

\section{INTRODUCTION}

The Badenian (Middle Miocene) deposition in the Ukrainian Carpathian Foredeep Basin took place mostly in the marine realm. Shortly after 13.81 Ma (de Leeuw et al., 2010), evaporite deposition started in some Central Paratethys basins (Peryt, 2006 with references therein). It was terminated by the last marine transgression in the Central Paratethys (Rögl, 1998) at 13.36 Ma (de Leeuw et al., 2013) or ca. 13.54 Ma (Hohenegger et al., 2014) which flooded a wide area in the Carpathian foreland as well as marginal parts of the Outer Carpathian accretionary wedge and the northern part of the Magura Nappe (Oszczypko et al., 2006; Kováč et al., 2007; Gozhyk et al.,

\section{* Corresponding author, e-mail: ndgedl@cyf-kr.edu.pl}

Received: May 5, 2016; accepted: June 6, 2016; first published online: June 9, 2016
2015). As a result, in the western Ukraine the shoreline shifted towards the NE (Fig. 1).

Our earlier study of pelites of the siliciclastic series occurring above the Badenian gypsum deposits and the overlying limestones and intercalated marls with abundant faunal assemblages in the Kudryntsi section located in the marginal part of the Late Badenian basin (Fig. 1) showed that this succession was deposited in variable environments (Peryt and Peryt, 2009; Gedl and Peryt, 2011). The sequence of dinoflagellate cyst and foraminiferal assemblages indicated a gradual deepening of the sea and decrease of salinity, from slightly increased to normal marine (Gedl and Peryt, 2011). In this paper we document the lithological and micropalaeontological (foraminifers, dinoflagellate cysts, palynofacies) differentiation of the deposits of the Late Badenian sea after the Badenian Salinity Crisis in another Ukrainian key section, Anadoly near Khotyn, located in the marginal part of the basin (Fig. 1). This section, however, shows a different lithological succession compared to Kudryntsi despite a generally similar palaeogeographical location (Fig. 1). 


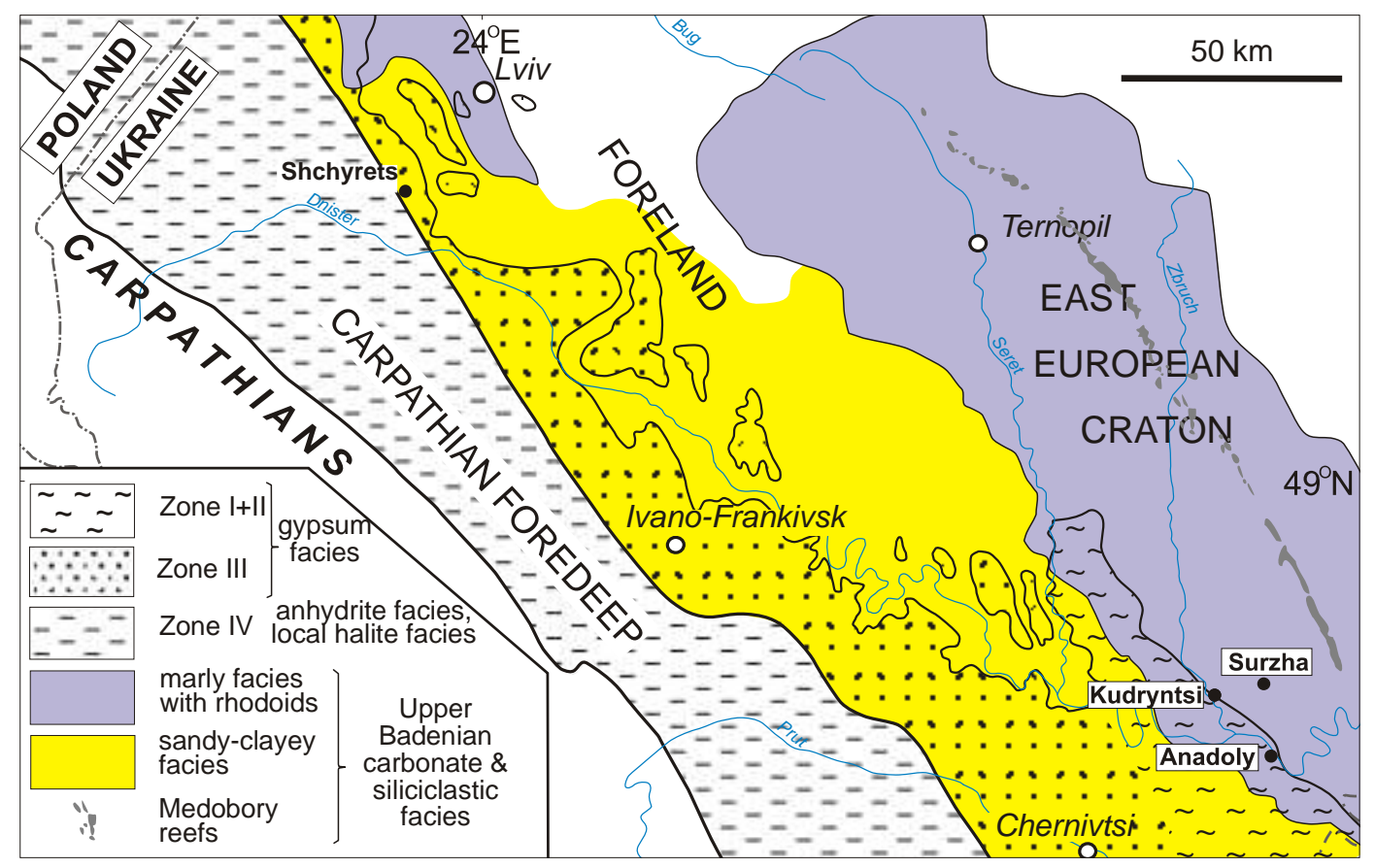

Fig. 1. Location map showing the mid-Badenian sulphate zones (after Peryt, 2006) and Upper Badenian facies in the Carpathian foreland (after Kudrin, 1966)

\section{GEOLOGICAL SETTING}

The studied section, Anadoly near Kamyanets Podilskyy (Fig. 1), is located in the foreland of the Carpathian Foredeep, which is filled mostly by Middle Miocene deposits (Oszczypko et al., 2006). In the outer zone of the Carpathian Foredeep and the foreland, the section of Middle Miocene deposits is clearly tripartite with marine siliciclastics and carbonates several tens to several hundreds of metres thick below the Badenian evaporites (Tyras Fm.), and marine to brackish siliciclastic deposits (up to $5 \mathrm{~km}$ thick) above the Badenian evaporites (Vjalov et al., 1981; Oszczypko et al., 2006). The Tyras Fm. includes mostly Ca-sulphate deposits and local Na-chloride deposits (Peryt, 2006 with references therein) and the Ratyn Limestone, which overlies and/or locally interfingers with gypsum deposits (Andreyeva-Grigorovich et al., 1997). The Ratyn Limestone is a deposit of complex origin (see Peryt et al., 2012); its marine facies is characterized by the presence of marine fauna (Peryt and Peryt, 1994; Peryt et al., 2012). Deposits of the Tyras Fm. are overlain by sediments of the Kosiv Fm. consisting, in the outer zone of the Carpathian Foredeep, of silty grey clays which alternate with separate interbeds of loose silts, sandstones, tuffs, and tuffites (Andreyeva-Grigorovich et al., 1997). Towards the north-east, i.e., toward the basin margin, these clayey deposits are gradually passing into scallop or glauconitic marls, and then into calcareous marls and marly limestones with fine rhodoids; the thickness of the marginal facies of the Kosiv Fm. is usually 4 to $15 \mathrm{~m}$ (Łomnicki, 1897; Teisseyre, 1900). Further toward the basin margins, the marginal facies of the Kosiv Suite passes into the Pronyatyn Limestone (Teisseyre, 1900; Kudrin, 1966). Studencka et al. (2012) characterized the Upper Badenian section of the Surzha borehole located between Kudryntsi and Anadoly. The base of the profile consists of the Ternopil Mb. (6 $\mathrm{m}$ thick succession of coralline-algal marly limestones with two thin fine-grained sandy-silty intercalations) and the overly- ing Prut Mb. (7 m of predominantly laminated grey-green or grey-blue clayey silt with occasional sandy limestones).

At Anadoly, numerous outcrops of the Tyras Fm., represented by gypsum and the Ratyn Limestone, and the siliciclastic deposits of Ternopil Mb. of the Kosiv Fm., are found (Figs. 2 and 3). The gypsum is mostly recrystallised, fine-grained gypsum deposits that represent gypsum microbialite facies and alabastrine facies (facies M of Babel, 2005: fig. 4), ca. $8 \mathrm{~m}$ thick, are overlain by ca. $3 \mathrm{~m}$ thick bedded clastic and laminated gypsum (Peryt, 1996; Petrichenko et al., 1997: fig. $3 b, c)$. At the boundary between the gypsum and the Ratyn Limestone a few $\mathrm{cm}$ thick clay layers, followed by a celestite-bearing bed composed of sparitic limestone, occur (Sidorenko, 1904; Koltun et al., 1972). The gypsum-associated limestones of Anadoly referred to as the Ratyn Limestone are polygenic (see Peryt et al., 2012 for discussion) although often the upper parts of the Ratyn Limestone are marine (Peryt and Peryt, 1994; Peryt et al., 2012), often bioclastic grainstones and packstones, such as in the outcrop studied by us (Fig. 2B; GPS coordinates: N48²7.160', E26 ${ }^{\circ} 33.067^{\prime}$ - Anadoly I in Peryt et al., 2012).

The Ratyn Limestone (1.8 m thick) overlies the celestite-bearing bed and except for the uppermost $0.3 \mathrm{~m}$ is peloidal-microbial with common pseudomorphs after lenticular gypsum crystals. The uppermost part is bioclastic packstone-grainstone with foraminifers, bryozoans, ostracods, echinoderms and bivalves that are sometimes accompanied by rhodoids and intraclasts of limestones showing mudstone texture. Above the Ratyn Limestone, a section 5.3 m thick composed of dark grey mudstones with limestone intercalations was measured and sampled in the slope outcrop (GPS coordinates of this outcrop: N48 ${ }^{\circ} 2.137^{\prime}, E^{\circ} 6^{\circ} 33.019^{\prime}$ ) in 1996. In addition, two samples (Nos. 119 and 120) were taken in the outcrop located between the last outcrop and Anadoly I and shown in Figure 2C. X-ray diffraction study of the rocks overlying the Ratyn Limestone indicated that their mineralogical composition is quite stable throughout the section. In all studied samples calcite, quartz, 

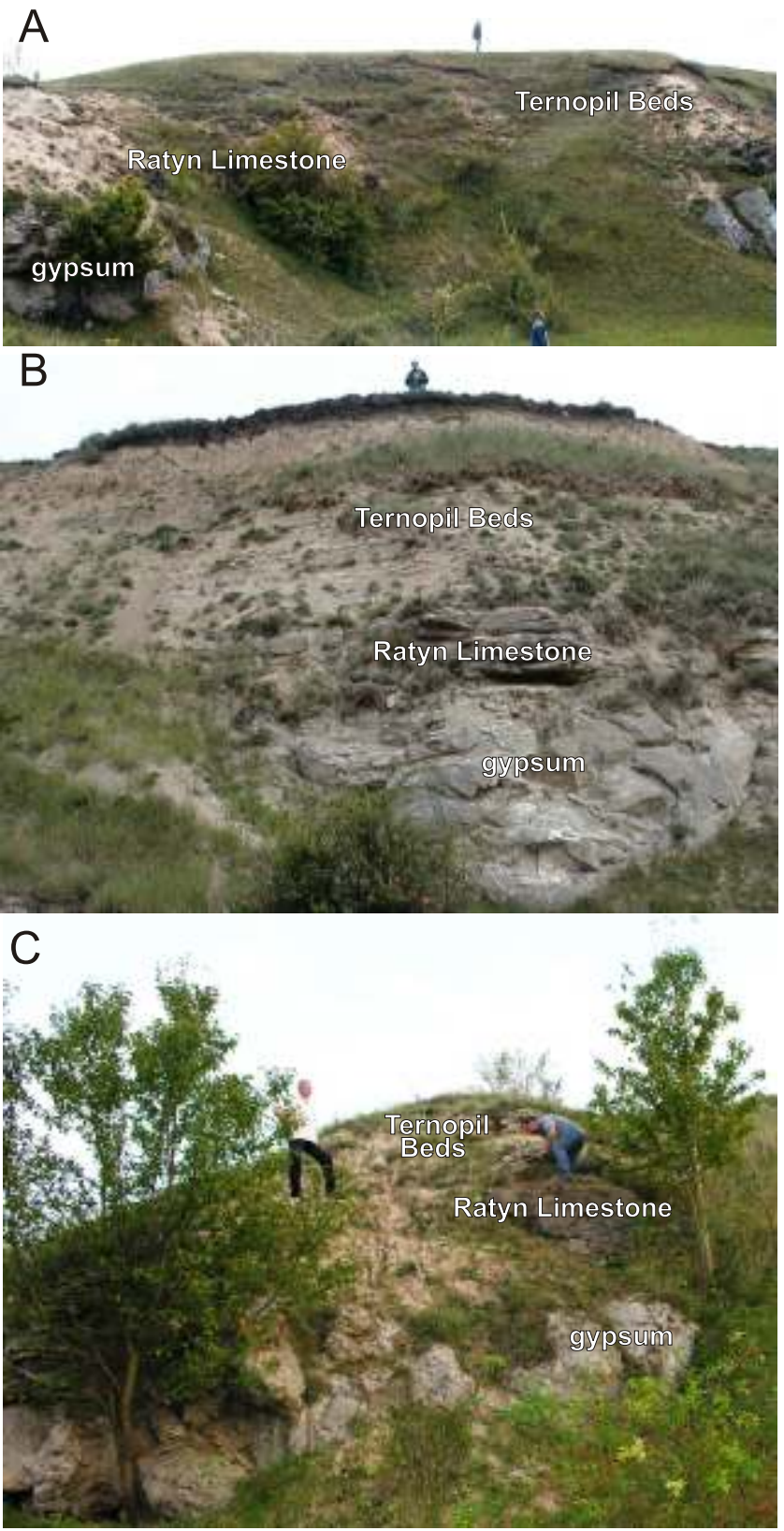

Fig. 2. Field photos showing the NE outcrops in the Anadoly area

smectite and (with exception of sample $\mathrm{M}-16$ ) illite were recorded. In the lower part of the section (up to sample M-13) zeolite occurs, and in its upper part (samples M-15, M-17-M-19) and additionally in sample M-9 feldspar occurs. Gypsum was noticed in sample M-9, M-11 and M-13.

\section{MATERIAL AND METHODS}

The section was measured and eleven samples (M-9 to M-19) were selected in 1996 and subsequently two samples were taken from the lowest part of the Ternopil Mb. for micropalaeontological studies in order to establish the presence of foraminifers and dinocysts. The location of samples studied is shown in Figure 3. Basal sample 119 collected $5 \mathrm{~cm}$ above the Ratyn Limestone is dark brownish calcareous clay with fragments of coralline algae. Higher samples are pale beige to white coralline algal limestone mixed with dark clay (120, M-9, $M-10, M-11, M-12)$ and with gypsum crystals (M-13-M-16). Sample M-17 is a pale beige, porous, non-calcareous gaize. Two uppermost samples (M-18 and M-19) are pale celadon calcareous clay.

Washed residues for foraminiferal study were obtained from the rocks by disaggregation using $\mathrm{Na}_{2} \mathrm{SO}_{4}$. An amount of about 300-400 specimens of foraminifers $>63 \mu \mathrm{m}$ size fraction was picked for the faunal analyses. The classification scheme used follows Loeblich and Tappan (1987) and Cicha et al. (1988). The specimens were studied and documented using a Philips XL20 SEM.

The palaeoenvironmental interpretation based on foraminifers applies the requirements of present-day representatives of the recorded taxa (e.g., Thomas, 1980; Van der Zwaan, 1982; Lutze and Coulbourn, 1984; Culver, 1988; Lutze and Thiel, 1989; Verhallen, 1991; Murray, 1991, 2006; Sjoerdsma and van der Zwaan, 1992; Jorissen et al., 1992, 1995; Langer, 1993; Kaiho, 1994; Hayward et al., 1997, 2010; Chendeş et al., 2004; Kaminski, 2012; Hayward, 2014, Arslan et al., 2016). Some taxa are characterized by opportunistic behaviour; they are tolerant to dysoxia and increased bottom-water salinity (e.g., Bulimina, Bolivina, Hanzawaia, Uvigerina). Elphidium (keeled) is epifaunal, prefers sandy substrate marine temperate-warm waters $0-50 \mathrm{~m}$ deep (inner shelf) and of salinity range 35-70\%. Among hauerinids, Quinqueloculina is epifaunal, lives free or is clinging plants or sediment in marine-hypersaline (salinity 32-65\%o), cold-warm waters 0-40 m deep, in shelf, rarely bathyal environment. Triloculina is epifaunal, lives free or is clinging mud, sand, plants, lives in marine-hypersaline (salinity 32-55\% ), cold waters $0-40 \mathrm{~m}$ deep in inner shelf environments, although some species are bathyal. Pyrgo is epifaunal, lives free or is clinging plants or sediment, in marine cold shelf-bathyal waters. Lobatula lobatula is epifaunal, is clinging or attaches firm substrates in marine temperate-warm waters 0-50 m deep, in lagoon and inner shelf environments.

Astronion is epifaunal-infaunal, lives free or clinging in marine, cold waters, in inner shelf-bathyal zones. Porosononion, by analogy to non-keeled Elphidium, is infaunal, prefers muddy and sandy substrate, inner shelf depth and a wide salinity range $(0-70 \%$ o). Neoconorbina is epifaunal, lives clinging or attached on firm substrates in marine, temperate waters, in inner shelf zone. Rosalina is epifaunal, lives clinging or attached on firm substrates in marine, temperate-warm waters 0-100 $\mathrm{m}$ deep, in lagoons and inner shelf zone. Cibicidoides is epifaunal, inhabits hard substrates in marine cold water of shelf-bathyal zones. Uvigerina is mainly infaunal, some species are epifaunal, lives free on muddy sediment in marine cold waters 100 to $>4500 \mathrm{~m}$ deep, in shelf-bathyal zones. Melonis is infaunal, lives in mud and silt, in marine waters of temperature $<10^{\circ} \mathrm{C}$, in shelf-bathyal zones.

Globocassidulina is infaunal, lives in mud in marine temperate-cold waters of shelf-bathyal zones.

Bulimina and Bolivina live in inner shelf-bathyal zones. Bolivina is infaunal-epifaunal, prefers muddy sediment and cold to warm environments, and Bulimina is infaunal, prefers mud to fine sand, and cold-temperate conditions. Heterolepa is epifaunal and lives on hard substrates in marine cold-water shelf-bathyal environments. Pullenia and Hoeglundina are infaunal forms favouring muddy marine cold-water middle shelf-bathyal zones.

Benthic and planktonic fauna characteristics and the $\mathrm{P} / \mathrm{B}$ ratio [100x(planktonic foraminifera/total foraminifera)] were used to estimate palaeobathymetry (Murray, 1976; Hemleben et al., 1989; Van Hinsbergen et al., 2005; Kouwenhoven and van der Zwaan, 2006). 


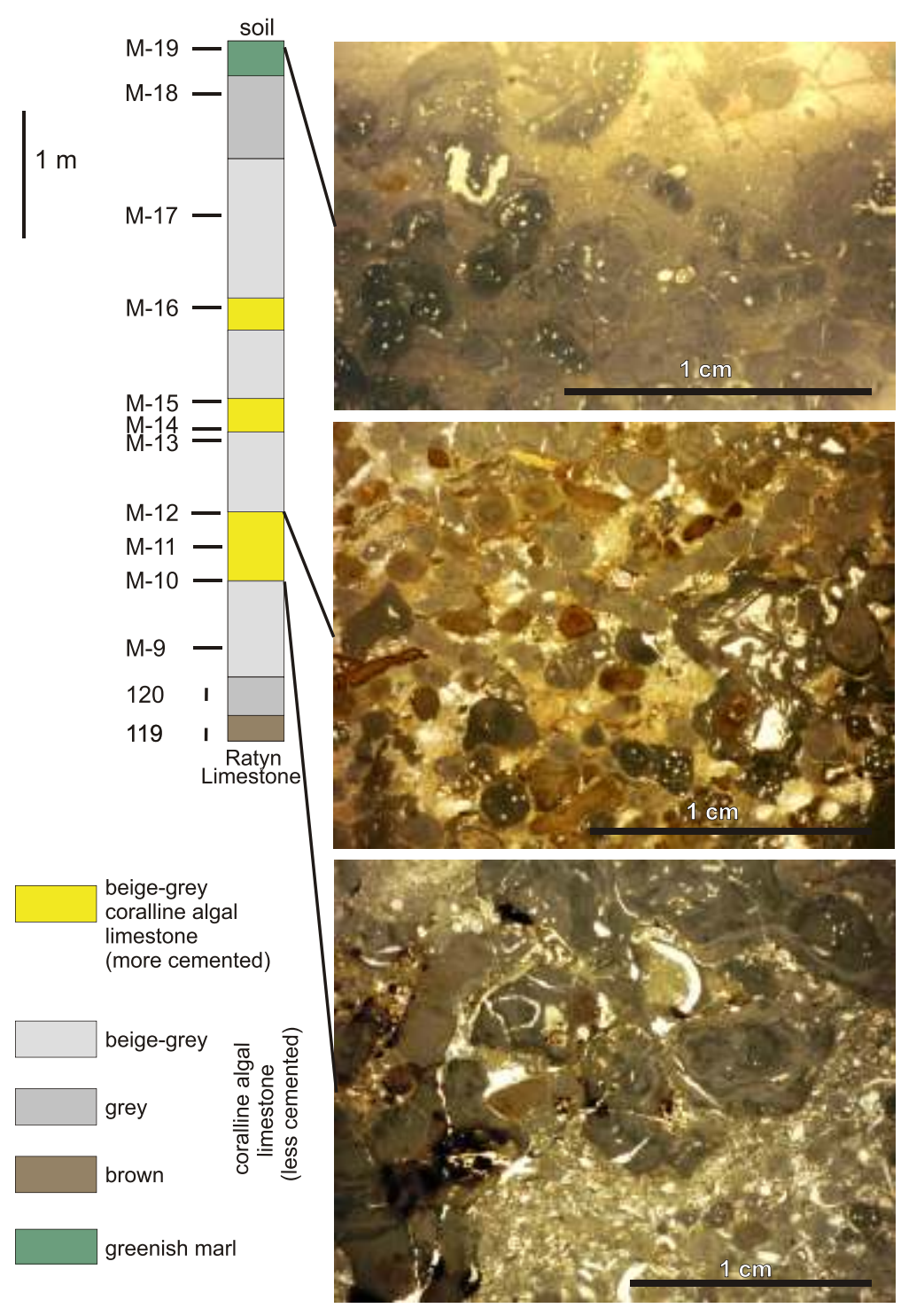

Fig. 3. Upper Badenian Anadoly section showing sample locations, lithology and microfacies

To estimate the level of oxygenation of the sea-floor the benthic foraminifers were grouped into oxic, suboxic and dysoxic indicators according to Thomas (1980), van der Zwaan (1982, 1983), Verhallen (1991), Murray (1991, 2006), Jorissen et al. (1992), Kaiho (1994), Bernhard and Sen Gupta (1999), Gebhardt, 1999; Kouwenhoven and van der Zwaan (2006) and Kaminski (2012).

The following taxa are included into the oxic group: Elphidium spp., hauerinids, Lobatula lobatula, Neoconorbina sp., Rosalina obtusa, Cibicidoides spp., Heterolepa dutemplei, Hanzawaia boueana, Sigmoilinita tenuis. Oxic indices represent epifaunally living species. Taxa tolerant of suboxic environments are: Porosononion spp., Astrononion perfossum, Nonion commune, Melonis pompilioides, Pullenia bulloides, P. miocenica, Sphaeroidina bulloides, Hoeglundina elegans, and taxa tolerant of dysoxic environments - Bulimina spp., Uvigerina spp., Bolivina spp., Globocassidulina oblonga, Reussella spinulosa.

Foraminifers tolerant of suboxic environments represent mostly shallow infaunally living species, while foraminifers tolerant of dysoxic environments represent mostly deep infauna and species with opportunistic behaviour. They are commonly used as stress markers (e.g., van der Zwaan et al., 1999; van Hinsbergen et al., 2005).

Planktonic foraminifers were used to interpret palaeoclimatic conditions. They were grouped into cool-temperate indices (Globigerina bulloides, $G$. praebulloides) and warm indices (Globigerinoides spp.; Szczechura, 1982, 1984, 2000; Hemleben et al., 1989; Spezzaferi et al., 2002; Bicchi et al., 2003; Peryt, 2013; Holcová et al., 2015).

The samples for palynology were processed in the Micropalaeontological Laboratory of the Institute of Geological Sciences, Polish Academy of Sciences, Kraków. Standard palynological procedures were applied, including 38\% hydrochloric acid $(\mathrm{HCl})$ treatment, $40 \%$ hydrofluoric acid (HF) treatment, heavy liquid $\left(\mathrm{ZnCl}_{2}+\mathrm{HCl}\right.$; density $\left.2.0 \mathrm{~g} / \mathrm{cm}^{3}\right)$ separation, ultrasound for $10-15 \mathrm{~s}$ and sieving at $15 \mathrm{~m}$ on a nylon mesh. No nitric acid $\left(\mathrm{HNO}_{3}\right)$ treatment was applied. The quantity of rock processed was approximately $60 \mathrm{~g}$ for coralline algal limestone samples, and $20 \mathrm{~g}$ for clay samples. Two microscope slides were made from each sample using glycerine jelly as a mounting medium; approximately $25 \%$ of the residuum was used for each slide. The rock samples, palynological residues and slides are stored in the collection of the Institute of Geological Sciences, Polish Academy of Sciences, Kraków. All marine palynomorphs were counted from two slides. No statistical proxies were calculated due to very low frequency, only percentages.

Isotopic analyses of three bulk limestone samples (M-10, M-12 and M-19) were done at the Institute of Physics, University Maria Curie-Skłodowska, Lublin, Poland; see Peryt et al. (2004) for detailed procedure applied.

\section{RESULTS}

\section{FORAMINIFERS}

The preservation of foraminifers is good to moderate; in sample $\mathrm{M}-17$ calcareous tests of benthic foraminifers are etched; in some others they show traces of mechanical damage that may indicate resedimentation. 54 species of benthic foraminifers and 10 planktonic ones have been identified. Benthic foraminifers are represented mainly by calcareous forms; agglutinated tests are very rare and only a few species are recorded, i.e., Siphotextularia concava and Semivulvulina sp. Planktonic foraminifera appear in the upper part of the studied succession (samples $M-13$ to $M-19$ ). They form from 3 to $10 \%$ of the assemblage (40\% in sample $M-13)$. Globigerina bulloides, G. praebulloides and Globigerinoides spp. are the most common species.

The stratigraphically and palaeoenvironmentally important species of foraminifers are shown in Figures 4-6; planktonic foraminifers are illustrated in Figure 4 and benthic foraminifers in Figures 5-6. The abundance fluctuations of foraminifers are shown in Figure 7.

Five benthic foraminiferal assemblages are recognized in the studied succession: Elphidium/Lobatulal Astrononion Assemblage (Assemblage A), Hauerinidae Assemblage (Assemblage B), Cibicidoides/Lobatula Assemblage (Assemblage C), Porosononion Assemblage (Assemblage D) and Uvigerina/Bulimina Assemblage (Assemblage E; Fig. 7). In the lower and middle parts of the 


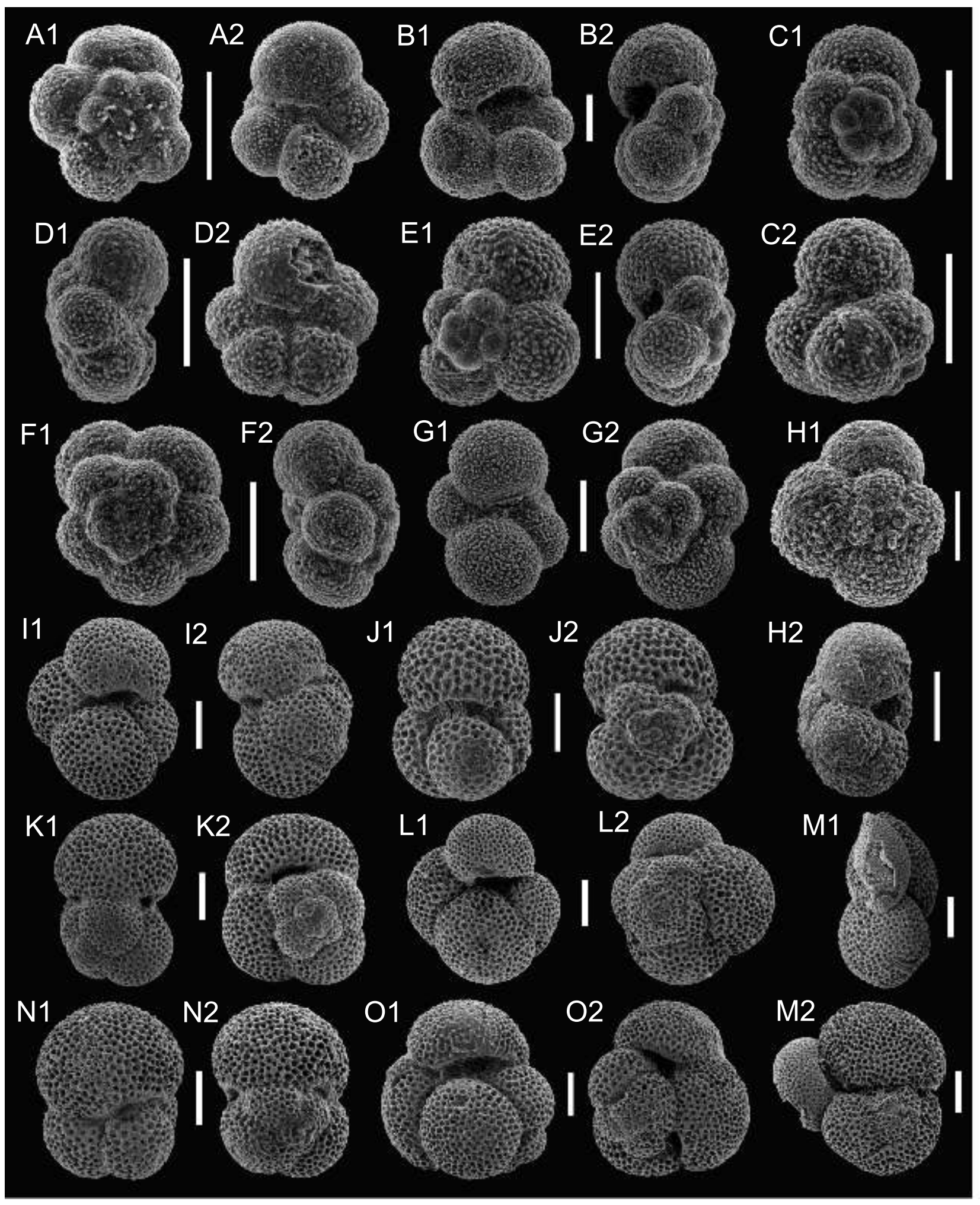

Fig. 4. Planktonic foraminifers from the Upper Badenian of Anadoly (scale bars $=100 \mu \mathrm{m}$ )

A, D - Tenuitellinata juvenilis; B, H - Globigerina bulloides; C - Globigerinita uvula; E - Globigerina praebulloides; F - Globigerina tarchanensis; G - Globigerina falconensis; I, L, O - Globigerinoides quadrilobatus; J, K, N - Globigerinoides trilobus; M - Globigerinoides sp. 


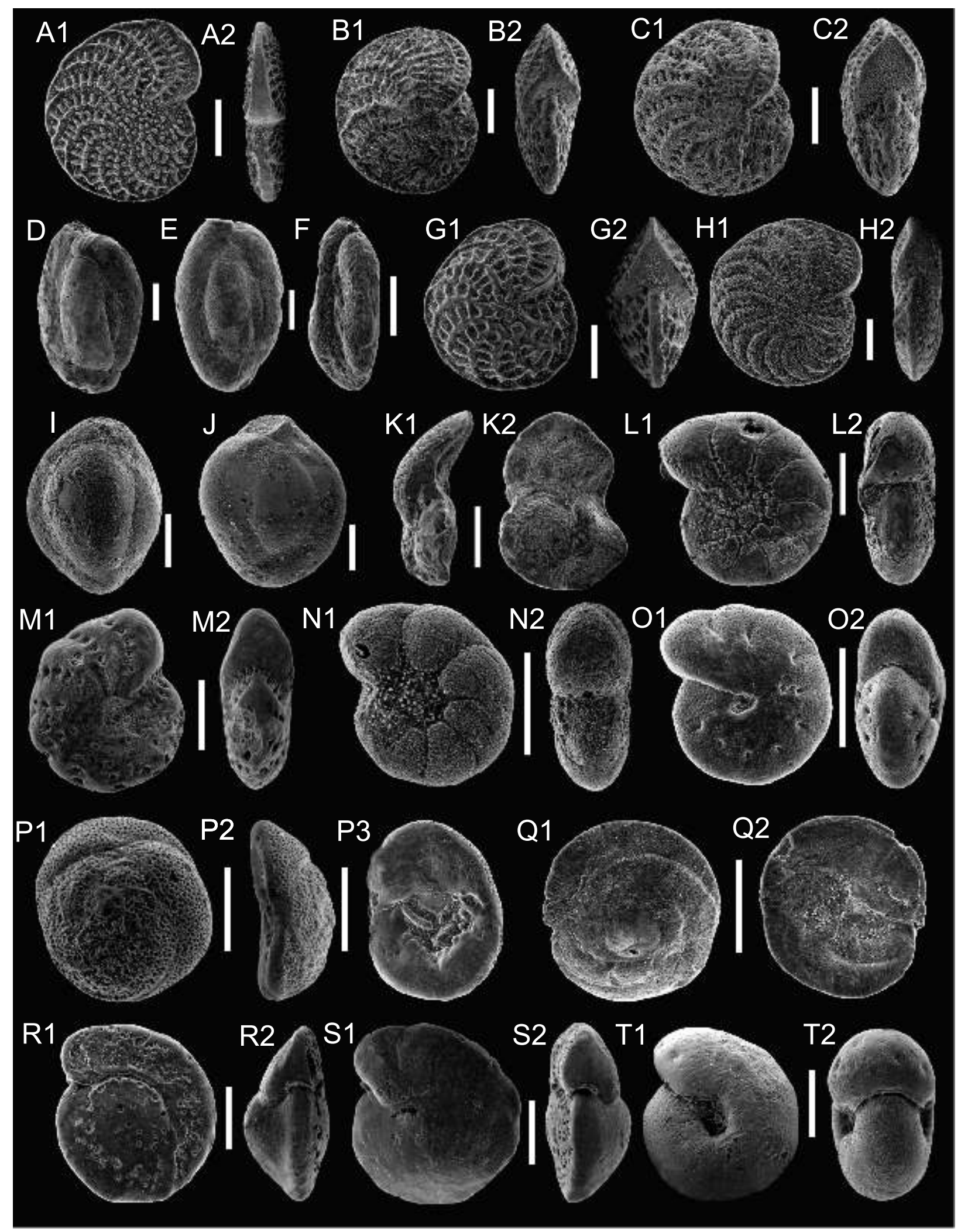

Fig. 5. Benthic foraminifers from the Upper Badenian of Anadoly (scale bars $=200 \mu \mathrm{m}$ )

A, H - Elphidium fichtelianum (sample 120); B - Elphidium joukovi (sample 119); C - Elphidium macellum (sample 119); D, E Quinqueloculina sp. (sample 120); F - Pseudotriloculina consobrina (sample 120); G - Elphidium crispum (sample M-13); I, J Triloculina gibba (sample M-15); K - Lobatula lobatula (sample 119); L - Porosononion granosum (sample 120); M - Elphidium advenum (sample 119); N - Porosononion martkobi (sample 120); $\mathbf{O}$ - Astrononion perfossum (sample 119); P - Rosalina obtusa (sample 119); $\mathbf{Q}$ - Neoconorbina schreibersi (sample 120); R, S - Cibicidoides pseudoungerianus (sample M-13); T - Melonis pompilioides (sample M-13) 


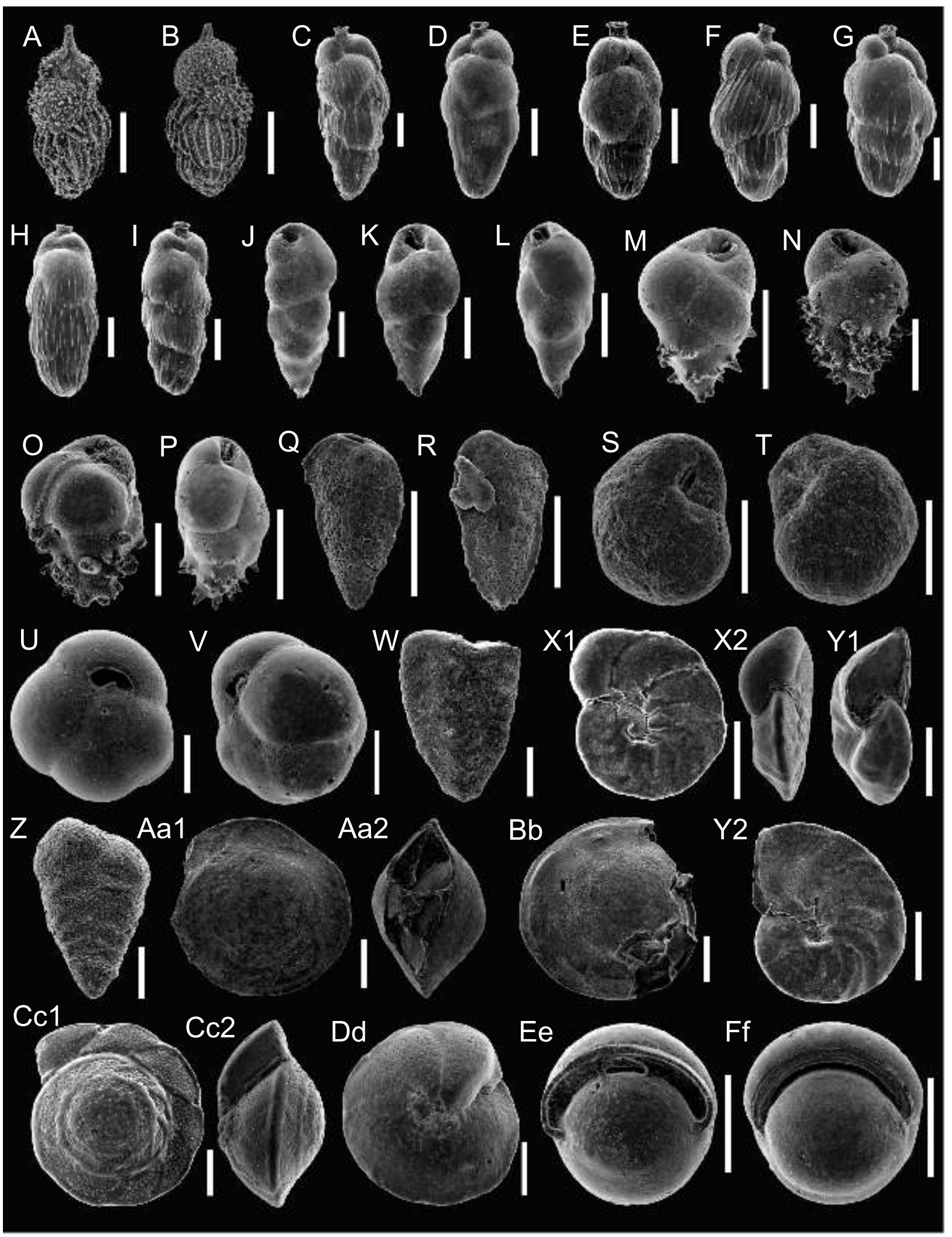

Fig. 6. Benthic foraminifers from the Upper Badenian sequence of Anadoly (scale bars $=\mathbf{2 0 0} \mu \mathrm{m}$ )

A, B - Uvigerina aculeata (sample M-19); C-G - Uvigerina semiornata (sample M-19); H, I- Uvigerina brunnensis (sample M-19); J-L - Bulimina insignis (sample M-19); M-P - Bulimina aculeata (sample M-19); Q - Bolivina dilatata (sample M-19); R - Bolivina maxima (sample M-19); S, T - Globocassidulina oblonga (sample M-16); U, V - Sphaeroidina bulloides (sample M-19); W Semivulvulina sp. (sample M-13); X, Y - Hanzawaia boueana (sample M-18); Z - Siphotextularia concava (sample M-15); Aa, Bb Hoeglundina elegans (sample M-19); Cc, Dd - Heterolepa dutemplei (sample M-18); Ee - Pullenia miocenica (sample M-19); Ff Pullenia bulloides (sample M-19) 


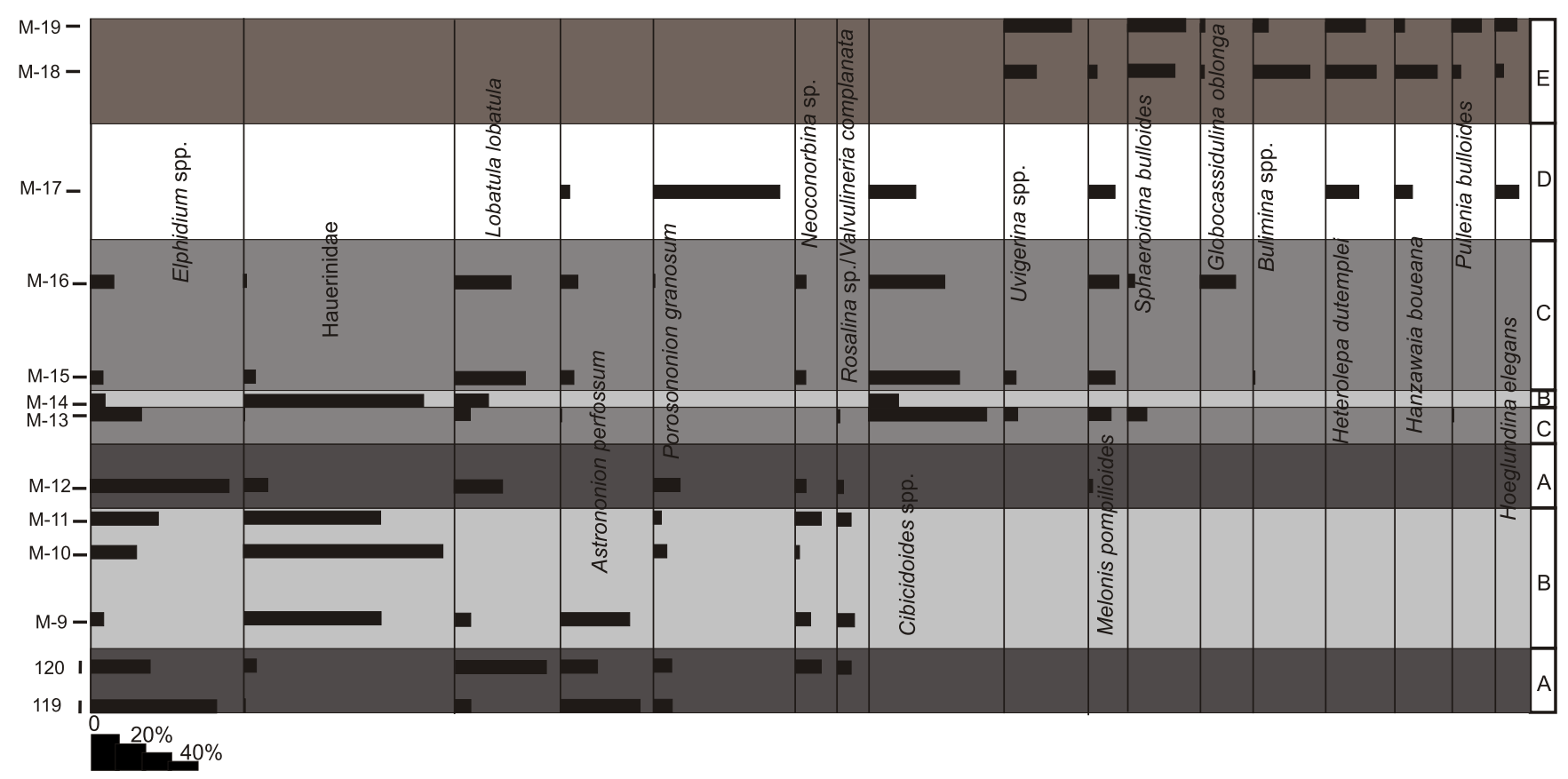

Fig. 7. Benthic foraminiferal assemblages and relative abundances of foraminifer groups within the Upper Badenian sequence of Anadoly

section assemblages $A, B$ and $C$ intercalate. Assemblage $A$ is dominated by Elphidium represented by several species, e.g., $E$. macellum, E. fichtelianum, E. joukovi, E. crispum, E. advenum. Elphidium forms 22 to $53 \%$ of the assemblage, Lobatula lobatula6 to $35 \%$ and Astrononion perfossum - up to 31\%. Porosonion spp., Neoconorbina sp. and Rosalina obtusa are also rare to common components of the assemblage. Assemblage $A$ is recorded in samples 119, 120 and M-12.

Assemblage $B$ is characterized by a high dominance of hauerinids. They form 50 to $75 \%$ of the assemblage; common is Elphidium (6-24\%); Lobatula lobatula less common than in the Assemblage A (13\% in sample M-14). Porosononion and Rosalina are minor components. Assemblage $\mathrm{B}$ is recorded in samples $\mathrm{M}-9, \mathrm{M}-10, \mathrm{M}-11$ and $\mathrm{M}-14$.

Assemblage $\mathrm{C}$ is dominated by Cibicidoides spp., comprising 28 to $45 \%$ of the assemblage. Another important contributor to the assemblage is Lobatula lobatula which reaches $35 \%$. Beside dominating Cibicidoides spp., for the first time in this succession Uvigerina sp., Melonis pompilioides and Sphaeroidina bulloides appear which are minor components. Assemblage $C$ occurs in samples M-13, M-15 and M-16.

Assemblage D differs from Assemblages A, B and C by the total absence of Elphidium, hauerinids and Lobatula which were dominant or common components of those assemblages. Assemblage $D$ is dominated by Porosononion (47\%) represented by $P$. granosum, $P$. martkobi and $P$. tumidulus. Cibicidoides spp., Melonis pompilioides, Heterolepa dutemplei and Hoeglundina elegans are also common. Assemblage D was found in sample M-17.

Assemblage $E$, recorded in samples $M-18$ and $M-19$, is characterized by low dominance and higher diversity than all other assemblages. Uvigerina spp. (Uvigerina aculeata, U. brunnensis, U. semiornata, Uvigerina sp.) (12-26\%), Bulimina spp. (Bulimina aculeata, B. insignis, Bulimina sp.) (6-21\%), Sphaeroidina bulloides (18-21\%), Heterolepa dutemplei (15-19\%), Hoeglundina elegans (3-8\%) and Pullenia spp. $(3-11 \%)$ are common in this assemblage.

\section{DINOFLAGELLATE CYSTS AND PALYNOFACIES}

All samples yielded low amounts of palynological organic matter, consisting mainly of small-sized (below $20 \mathrm{~m}$ ) equidimensional, exceptionally elongated, easily disintegrable black opaque phytoclasts. Such phytoclasts usually constitute $80-90 \%$ of the total. Dark brown phytoclasts, with partially preserved vascular structures, are rare. A characteristic feature is near complete lack of sporomorphs; bisaccate pollen grains occur infrequently, commonly as a few grains per slide (Fig. 8). Their presence may be, however, a recent contamination, as some samples contain a relatively high admixture of recent vascular plant remains and fungi phycoma.

Marine palynomorphs are represented by dinoflagellate cysts and acritarchs; they are shown in Figures 9-11. Simple specimen and species numbers are shown in Figure 12.

Dinoflagellate cysts are rare to very rare; they occur commonly as a few to several specimens per slide (Fig. 8). A characteristic feature is a general taxonomical impoverishment of their assemblages, which consist of a few dominating species only (Polysphaeridium subtile, P. zoharyi, Lingulodinium machaerophorum, and Cleistosphaeridium placacanthum); their proportions differ from sample to sample.

Acritarchs are also very rare, they occur in some samples only (Fig. 8). Acritarchs are represented by Cymatiosphaera (C.? icenorum, C. sp.), and an acanthomorphitic form questionably referred to Micrhystridium (Fig. 11). Cymatiosphaera occurs in basal samples only. This genus is represented by two different morphotypes: chorate and proximate.

Chorate forms (Cymatiosphaera sp. A) are similar to a newly described species C.? icenorum (De Schepper and Head, 2014), but differ by acuminate endings of processes (Fig. $11 \mathrm{~A}-\mathrm{C}, \mathrm{F}-\mathrm{H}, \mathrm{X}$ ), which by $\mathrm{C}$.? icenorum are terminated with a platform-like structure; no pylome is observed in specimens from Anadoly.

Proximate forms include various species with solid crests that delimit polygonal fields; they differ by crest height, its mar- 


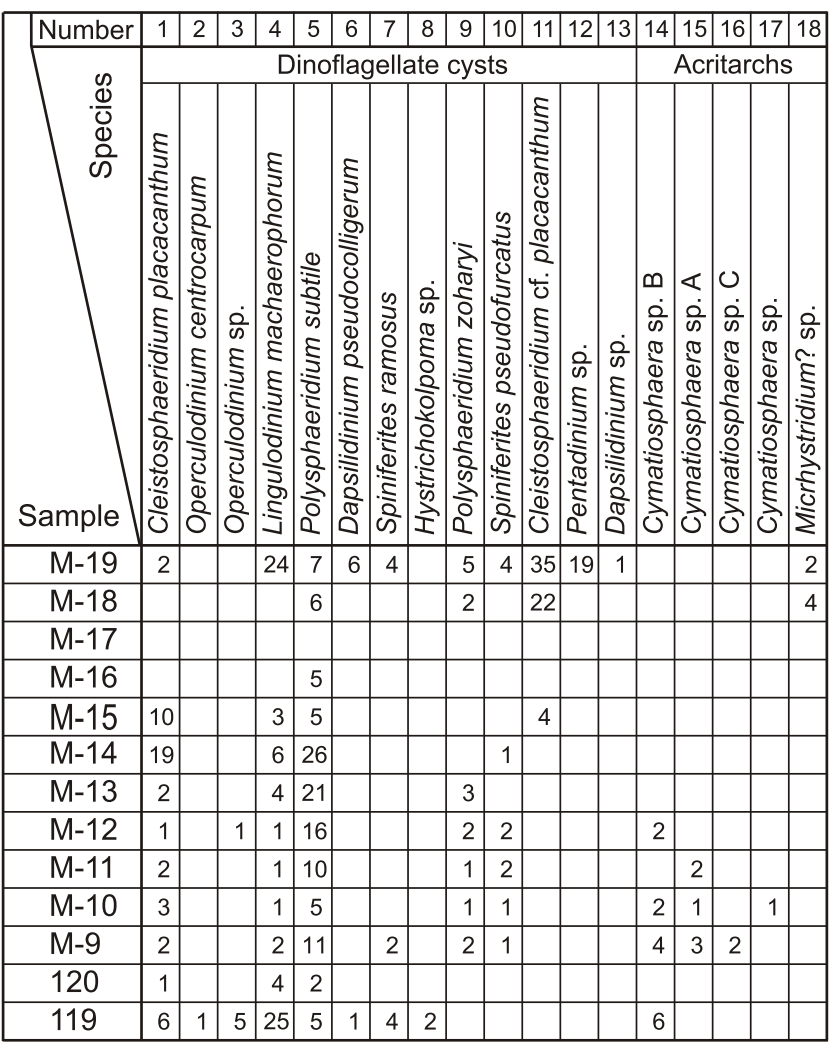

Fig. 8. Frequency of marine palynomorphs in the Anadoly section

gin type, field number and wall structure. Most common is Cymatiosphaera sp. B characterized by relatively large size (app. 25-40 m across), relatively low crests that form numerous polygonal fields, and variously developed bulbs in the centres of these fields; the bulbs are either very indistinct, hardly visible (Fig. 11K, O, P) or they are distinct, giving punctate appearance of the wall (Fig. $11 \mathrm{~L}-\mathrm{N}, \mathrm{V}, \mathrm{W})$; this species resembles most closely C.? deverteuilii of Quaijtaal et al. (2015) by its general morphology (dense network of polygonal fields) but differs by larger size and relatively lowers crests, and by the presence of the bulbs located centrally in each polygonal field; no pylome is observed in specimens from Anadoly. Cymatiosphaera sp. C includes spherical specimens with smooth wall and solid crests that form a few fields; no pylome is observed (Fig. 11D, E, I, J); this species shows morphological similarities to C.? fensomei of De Schepper and Head (2014) and C.? invaginata of Head et al. (1989). Another species of Cymatiosphaera (Fig. 11D-T, U) is slightly elongated, similar in shape to Impagidinium.

Basal sample 119 yielded relatively taxonomically diversified dinoflagellate cyst assemblage consisting of 8 species. It is dominated by Lingulodinium machaerophorum, which stands for over $50 \%$ of all identified dinoflagellate cysts. Polysphaeridium ( $P$. subtile) slightly exceeds $10 \%$ in this sample.

Sample 120 yielded very rare dinoflagellate cysts composed of three most common species in this section: Lingulodinium machaerophorum, Polysphaeridium subtile, and Cleistosphaeridium placacanthum; L. machaerophorum, similarly as in the lower sample, is the most frequent.

Dinoflagellate cyst assemblages from higher samples M-9 to M-13 consist generally of the same species (associated by rare Spiniferites and Operculodinium); they are dominated by Polysphaeridium (mainly $P$. subtile), which proportion increases upwards, to reach $80 \%$ in sample $\mathrm{M}-13$. Basal part of the section studied (up to sample M-12) yielded acritarchs of the genus Cymatiosphaera; this genus is absent from the higher part.

Sample M-15 yielded a similar taxonomically impoverished assemblage, which is distinguished by dominating Cleistosphaeridium placacanthum (>60\%; Polysphaeridium - 22\%). An even more impoverished assemblage occurs in higher sample M-16 in which a monospecific assemblage of Polysphaeridium subtile was found. No aquatic palynomorphs occur in sample M-17.

Two topmost clay samples $\mathrm{M}-18$ and $\mathrm{M}-19$ yielded two different assemblages. Lower sample $\mathrm{M}-18$ yielded an assemblage that resembles the ones from the basal part of section - it consists of Polysphaeridium and Cleistosphaeridium only (C. cf. placacanthum dominates $->70 \%$ ). Assemblage from the sample $\mathrm{M}-19$, in turn, is characterized by the highest taxonomical diversity - 10 species; most frequent are: $C$. cf. placacanthum (34\%), Lingulodinium machaerophorum (22\%), and Pentadinium sp. (18\%). Polysphaeridium ( $P$. subtile and $P$. zoharyi) hardly exceeds $10 \%$ in this sample. Acanthomorphitic acritarchs Micrhystridium? sp. occur in both samples.

A characteristic feature of the Anadoly assemblages is the lack of dinoflagellate cysts that are assumed to be offshore species (Nematosphaeropsis, Impagidinium) which inhabit waters of open marine basins (see e.g., Morzadec-Kerfourn, 1977; Wall et al., 1977; Harland, 1983; Brinkhuis, 1994).

\section{CARBON AND OXYGEN ISOTOPES}

Isotopic analyses of three samples studied (M-10, M-12 and $\mathrm{M}-19)$ yielded $\delta^{13} \mathrm{C}$ values $(2.13 \%,-2.54$ and $-1.69 \%$, respectively) and $\delta^{18} \mathrm{O}$ values $(-2.18 \%$ o, -2.73 and $-1.78 \%$, respectively) that fall within the field of Badenian marine sediments (e.g., Kováčová and Hudáčková, 2009; Kováčová et al., 2009).

\section{INTERPRETATION}

The taxonomic composition of foraminiferal assemblages indicates that the lower part of the studied deposits originated in a shallow water marine environment (about $20 \mathrm{~m}$ deep) with well oxygenated bottom waters (Fig. 12). Foraminifers included in the oxic group form in these assemblages from 76 to $99 \%$ of the total. Only in the lowest sample oxic species composed $55 \%$ of the assemblage. Keeled species of Elphidium, hauerinids and Lobatula lobatula were dominant groups of foraminifera in assemblages $A$ and $B$. They represent epiphytic foraminifera (Langer, 1993) which live free or clinging to plants or firm substrates, in temperate to warm waters, 0-50 m deep. Elphidium shows a preference for sandy siliciclastic substrates in the modern Arabian Gulf (Arslan et al., 2016). The taxonomic composition of the assemblages $A$ and $B$ enables to infer shallow (20 m deep) subtidal environment of normal marine salinity and temperate waters. Alternation of biofacies A and B may indicate changes of type of vegetation at the sea-floor or changes of energy of environment in time. In the middle of the section appears for the first time in the section planktonic foraminifera. They are represented mainly by a few species of Globigerina and Globigerinoides which are shallow water forms. At the same time in the section Cibicidoides spp. appears, which dominate Assemblage $C$ representing an inner shelf environment with well-oxygenated bottom waters. In this assemblage the oxic group forms 67 to $80 \%$ of the total. According to Hohenegger (2005) the shallowest water depth for Cibicidoides ungerianus is $50 \mathrm{~m}$. In this assemblage another common con- 

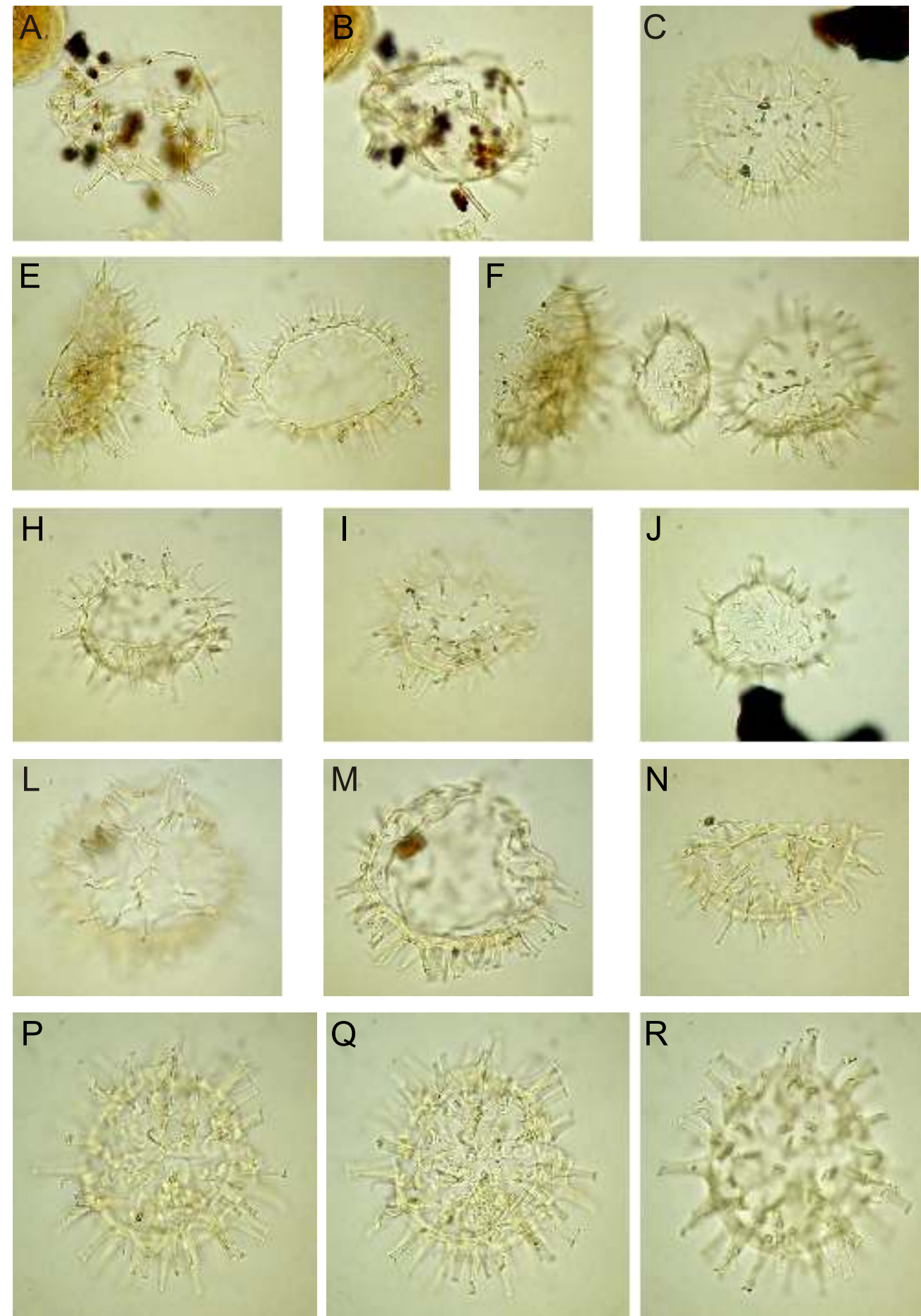
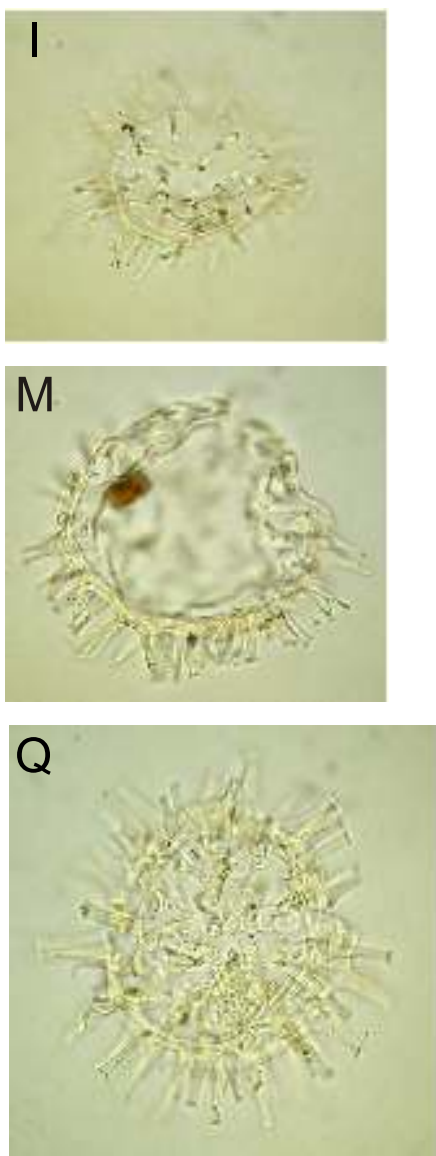
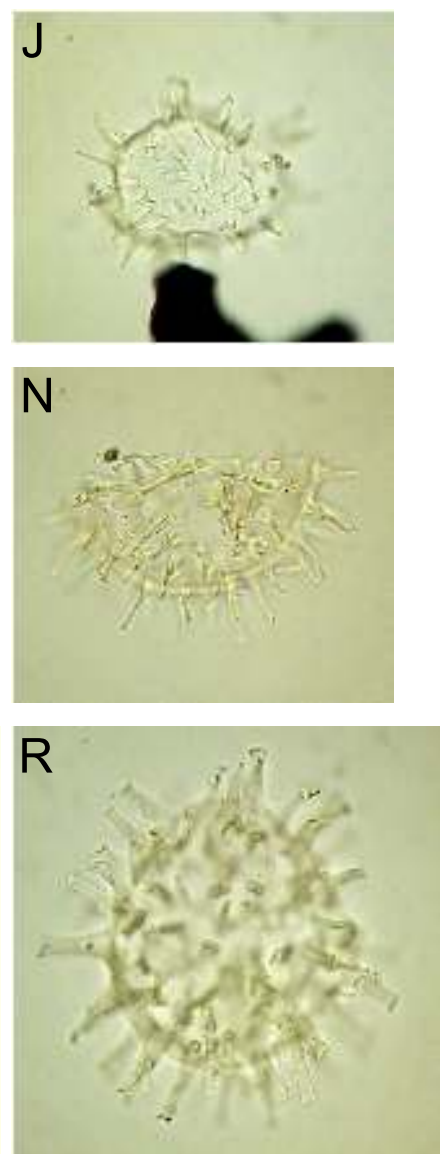
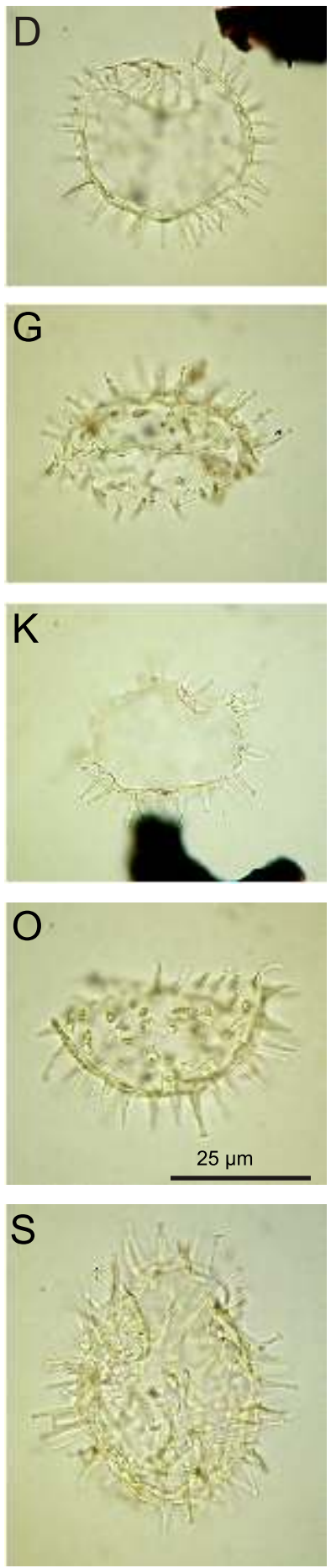

Fig. 9. Dinoflagellate cysts from the Anadoly section, genus Cleistosphaeridium

A, B - Polysphaeridium zoharyi (same specimen, various foci; sample M-10); C, D - Polysphaeridium subtile (same specimen, various foci; sample M-13); E, F - three specimens of Polysphaeridium subtile (same specimens, various foci; sample M-13); G - Polysphaeridium subtile (sample M-13); H, I - Polysphaeridium subtile (same specimen, various foci; sample M-13); J, K - Polysphaeridium subtile (same specimen, various foci; sample M-13); L, M - Polysphaeridium subtile (same specimen, various foci; sample M-12); N, O-Polysphaeridium subtile (same specimen, various foci; sample M-13); P-R - Polysphaeridium zoharyi (complete, same specimen, various foci; sample M-13); S - Polysphaeridium subtile (complete specimen; sample M-12); scale in O refers to all other microphotographs

stituent is Lobatula lobatula, which lives at inner shelf depths. This enables to interpret the deepening of the sea to $40-50 \mathrm{~m}$ in this time interval. The upper part of the studied succession originated in a shelf environment with decreasing oxygenation of bottom waters. Assemblage D represents a transitional time interval during which oxygenation of bottom waters decreased. It is expressed by huge increase in suboxic species (Fig. 12). Assemblage $D$ is composed by $29 \%$ of oxic and $71 \%$ of suboxic taxa. Assemblage E represents an interval with the highest deficiency of oxygen at the sea-floor. It is expressed mainly by low contributions of oxic forms (20-35\%) and high contributions of dysoxic taxa (>35\%) to the assemblage (Fig. 12). On the other 

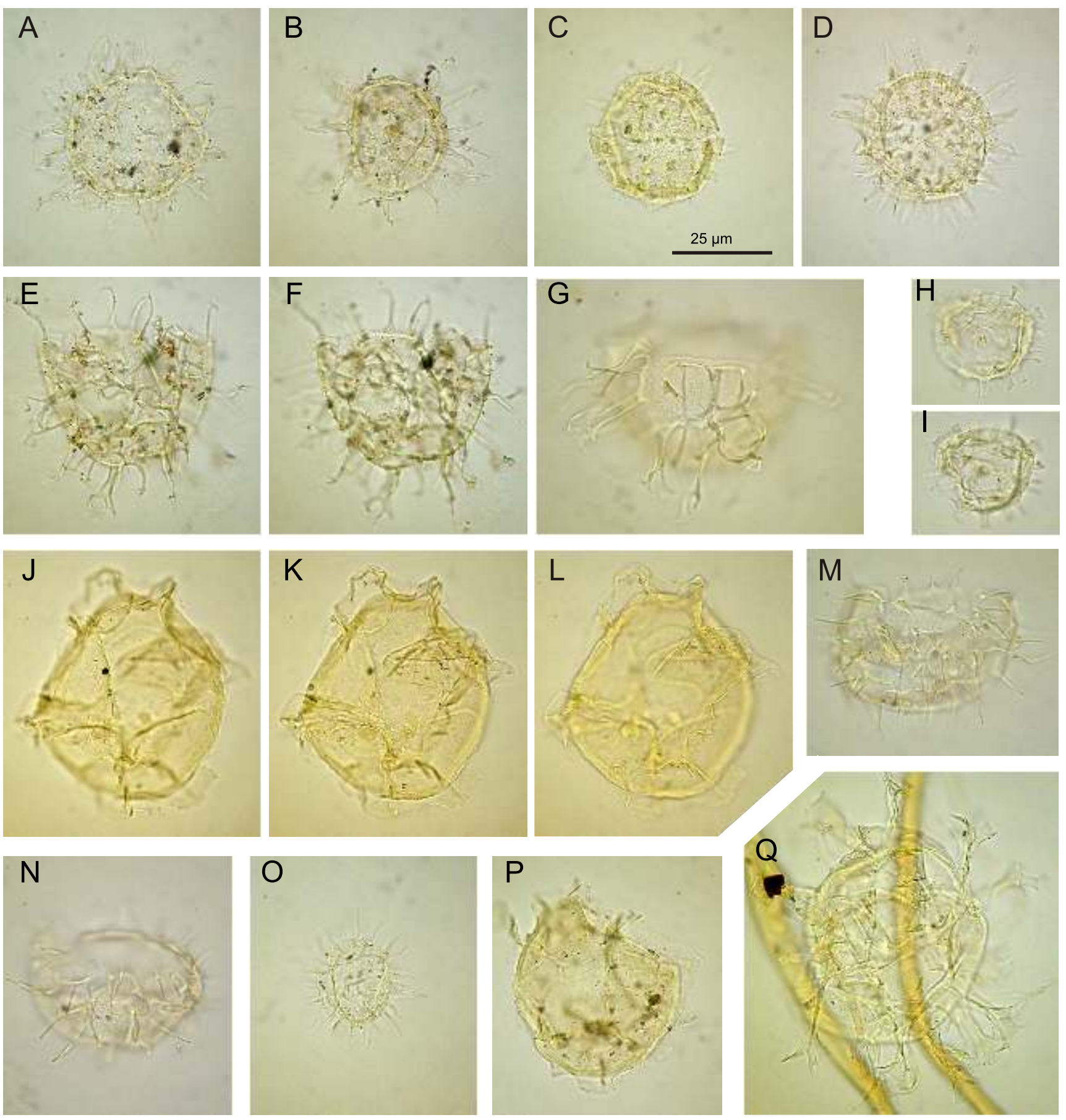

Fig. 10. Dinoflagellate cysts from the Anadoly section, genera Lingulodinium, Systematophora, Pentadinium, Dapsilidinium, and Spiniferites

A-D - Lingulodinium machaerophorum (A, B: sample M-14; C, D: sample M-19); E, F-Cleistosphaeridium placacanthum (same specimen, various foci; sample M-14); G - Cleistosphaeridium placacanthum (sample M-19); H, I - Dapsilidinium sp. (same specimen, various foci; sample M-19); J-L - Pentadinium sp. (same specimen, various foci; sample M-19); M - Cleistosphaeridium cf. placacanthum (sample M-19); $\mathbf{N}$ - Cleistosphaeridium cf. placacanthum (sample M-19); O - Dapsilidinium pseudocolligerum (sample M-19); P - Pentadinium sp. (same specimen, various foci; sample M-19); $\mathbf{Q}$ - Spiniferites pseudofurcatus (sample M-12); scale in C refers to all other microphotographs

hand the highest diversity in this assemblage and presence of several species of Uvigerina (deeper water foraminifers) and Hoeglundina elegans indicate middle shelf depths. The presence of Cibicidoides, Melonis, Pullenia, Heterolepa, Globocassidulina, Hoeglundina, Uvigerina and Bulimina common to dominant in the upper part of the studied interval indicate colder waters than in the lower part.

The taxonomically impoverished dinoflagellate cyst assemblage shows that the deposits studied originated in a marine, but restricted, environment. Dominating taxa like Polysphaeridium and Lingulodinium machaerophorum are usually associated with 

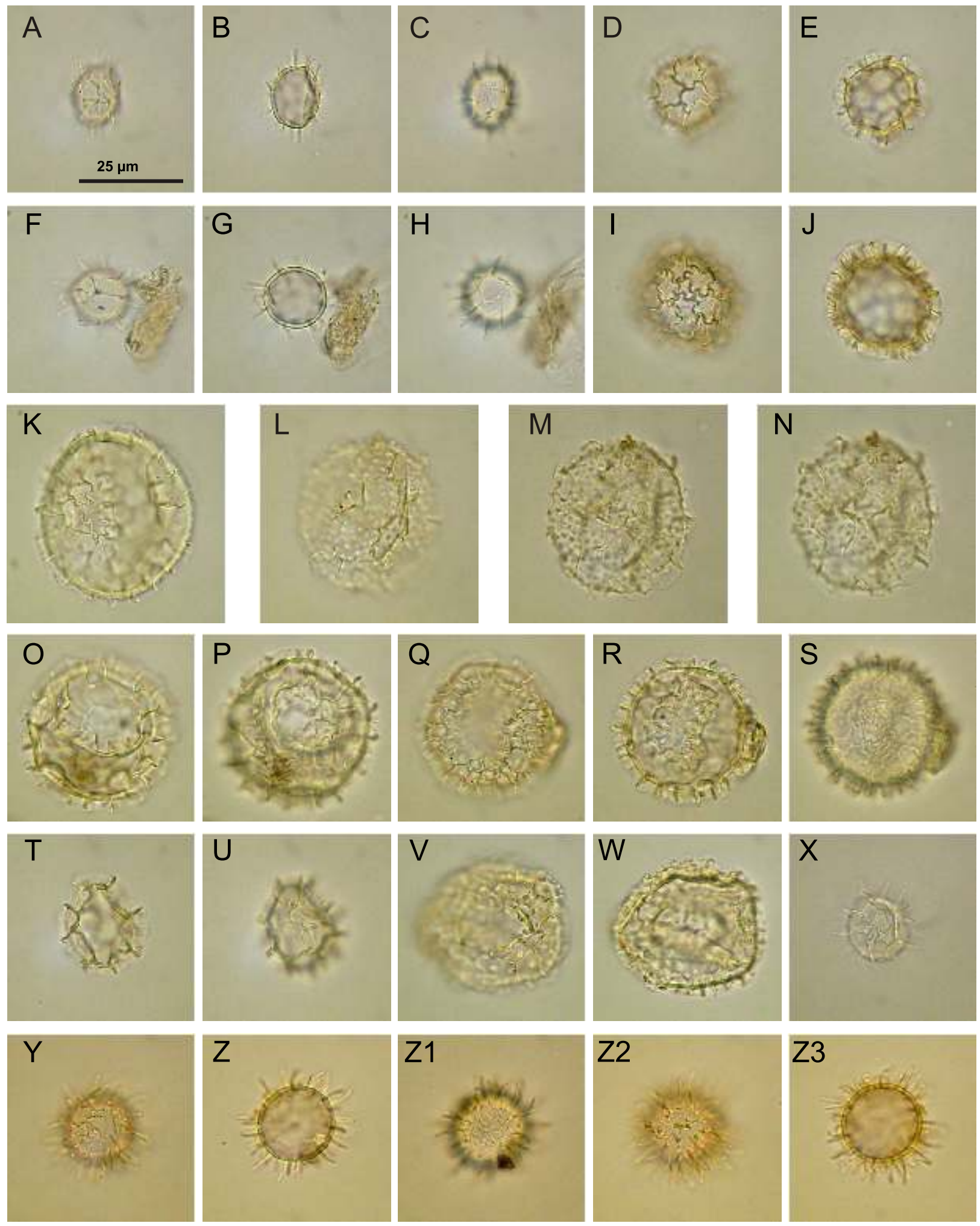

Fig. 11. Acritarchs from the Anadoly section

A-C - Cymatiosphaera sp. A (same specimen, various foci; sample M-9); D, E - Cymatiosphaera sp. C (same specimen, various foci; sample M-9); F-H - Cymatiosphaera sp. A (same specimen, various foci; sample M-9); I, J - Cymatiosphaera sp. C (same specimen, various foci; sample M-9); K - Cymatiosphaera sp. B (specimen with indistinct ornamentation of polygonal fields; sample M-10); L-N - Cymatiosphaera sp. B (specimen with distinct bulbs on the polygonal fields and low and faint ridges; same specimen, various foci; sample M-10); O, P - Cymatiosphaera sp. B (specimen with faintly developed bulbs on the polygonal fields; same specimen, various foci; sample M-10); Q-S - Cymatiosphaera sp. B (specimen with distinct bulbs on the polygonal fields and relatively high and thick ridges; same specimen, various foci; sample M-10); T, U - Cymatiosphaera sp. (same specimen, various foci; sample M-10); V, W - Cymatiosphaera sp. B (same specimen, various foci; sample M-12); $\mathbf{X}$ - Cymatiosphaera sp. A (sample M-11); Y-Z1 - Micrhystridium? sp. (same specimen, various foci; sample M-18); Z2, Z3 - Micrhystridium? sp. (same specimen, various foci; sample M-18); scale in A refers to all other microphotographs 


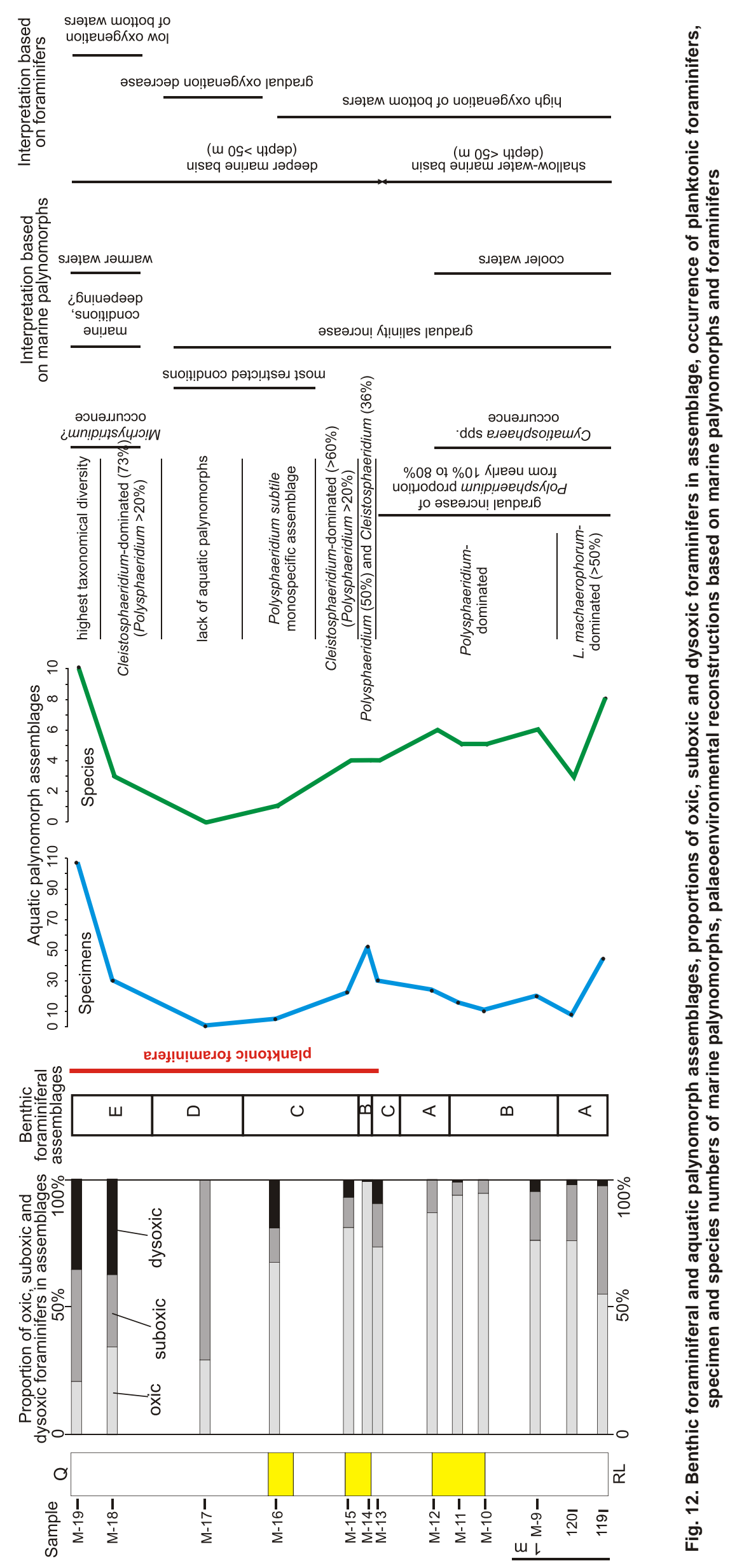


a near-shore, shallow marine environment (e.g., Wall et al., 1977; Edwards and Andrle, 1992). Some changes of their frequencies may be associated with salinity fluctuations or water depth changes. Lingulodinium machaerophorum is regarded as a euryhaline species, with its process length reflecting various salinity levels (e.g., Wall and Dale, 1973; Dale, 1996; Ellegaard, 2000; see also Sluijs et al., 2005: p. 296 for discussion). Polysphaeridium zoharyi (cyst of Pyrodinium bahamense), in turn, is commonly found in hypersaline waters (e.g., Bradford and Wall, 1984; Reichart et al., 2004), although Marret and Zonneveld (2003) suggested its euryhaline nature. The lowermost sample 119 yielded a relatively taxonomically rich assemblage (eight species) dominated by Lingulodinium machaerophorum; Polysphaeridium in this sample is rare. This indicates marine conditions, possibly with slightly lowered water salinity. A gradual decline of species frequency is observed higher up the section (sample 120 still shows a high proportion of $L$. machaerophorum but dinoflagellate cysts are very rare) associated with a gradua increase in the proportion of Polysphaeridium (Fig. 12). This trend likely reflects a gradual increase of water salinity, possibly associated with a shallowing trend. Its maximum can be placed around samples M-16 and M-17 where a Polysphaeridium monospecific assemblage (M-16) and lack of dinoflagellate cysts (M-17) reflects most restricted conditions. Higher up, an increase of species richness, particularly in the topmost sample M-19, reflects a gradual deepening of the basin and return of normal marine water conditions.

Somehow enigmatic in palaeoenvironmental reconstructions is the presence of Cleistosphaeridium. This genus, represented in Anadoly by $C$. placacanthum (former Systematophora placacantha) and a similar morphotype C. cf. placacanthum, has no well-known palaeoenvironmental preferences. Köthe (1990) included C. placacanthum in the Glaphyrocysta group, and following Williams' (1977) interpretation suggested open-marine preferences of this species. Brinkhuis (1994), in turn, proposed more inshore preferences of the Glaphyrocysta group (i.e., Glaphyrocysta and Areoligera, both morphologically similar to Systematophora) and located its optimal living conditions in an inner neritic zone of carbonate barriers. The latter interpretation is closer to the data obtained from other Miocene materials of western Ukraine at Kudryntsi and Shchyrets where Cleistosphaeridium placacanthum frequently occurs in marine shelf facies above the Ratyn Limestone (Gedl and Peryt, 2011; Peryt et al., 2014). These facies, although relatively shallow and proximal, seem to be located more offshore than the ones from the Anadoly section, as C. placacanthum occurs both at Kudryntsi and Shchyrets as a part of more diversified assemblages with frequent specimens of Spiniferites ramosus, Operculodinium, and rare offshore Nematosphaeropsis labirynthus and Impagidinium. Therefore, a near-shore environment can be suggested for motile stages of $C$. placacanthum during the Middle Miocene, although this species seemed to prefer a more offshore and/or less saline waters compared to the ones inhabited by Pyrodinium bahamense. Following this interpretation, it can be suggested that section intervals with frequent $C$. placacanthum - samples $\mathrm{M}-14$ and particularly $\mathrm{M}-15$, and the topmost interval (M-18 and M-19) - were deposited during periods of basin deepening or periods of sea water salinity decrease (the latter compared to hypersaline conditions favourable for Polysphaeridium).

Another aspect of palaeoenvironmental reconstruction of the Anadoly section is based on acritarchs. They are most frequent and diversified in the basal part of the section where various species of Cymatiospahera occur. The middle part of the section yielded no acritarchs, whereas its uppermost part yiel- ded an acanthomorphitic species determined as Micrhystridium? sp. This distribution may reflect water salinity/depth changes as inferred from dinoflagellate cysts, with the most restricted period during the deposition of the middle part of the studied succession. Alternatively, it also may be referred to sea water temperature. The prasinophycean Cymatiosphaera is commonly treated as an indicator of cold- and/or reduced salinity waters (Schreck et al., 2013 and references therein). Quaijtaal et al. (2015) suggested cold-water preferences of the Miocene species Cymatiosphaera? deverteuilii, a similar species to Cymatiosphaera sp. B, which is the most frequent among acritarchs in the basal part of the studied section. Hence, possible cold-water conditions can be suggested for at least the basal part of the Anadoly section. It is noteworthy that Cymatiosphaera was also found in warm-water Middle Badenian assemblages of Korytnica (Gedl, 1996: fig. 15L), but this is a different species than that occuring at Anadoly.

\section{DISCUSSION}

Comparison of foraminiferal assemblages from Anadoly with the Kudryntsi (see Gedl and Peryt, 2011) and Shchyrets (see Peryt et al., 2014) sections shows that the Anadoly assemblage is the richest one although the difference in number of species recorded is not essential (54 species of benthic foraminifers in Anadoly vs. 38 species in Shchyrets). In addition, rare agglutinated foraminifers occur in Anadoly whereas they are not recorded in Kudryntsi or in Shchyrets. Planktonic foraminifera (8 species) are present in the entire section of Shchyrets; whereas in the Anadoly section they (10 species) appear in the middle of the succession, and in the Kudryntsi section they are totally lacking.

It seems that assemblages II to IV from Kudryntsi roughly correspond to assemblages $\mathrm{A}$ and $\mathrm{B}$ from the Anadoly section. In both sections those assemblages are dominated by Elphidium spp. and hauerinids, indicating a shallow subtidal environment of normal marine salinity and temperate waters. Assemblages V to VII from Kudryntsi roughly correspond with Assemblage $C$ from the Anadoly section. The equivalents of assemblages $D$ and $E$ from Anadoly are not represented in the Kudryntsi section. It seems that the Kudryntsi section represents a stratigraphically shorter interval than that from Anadoly.

While comparing the Anadoly and Shchyrets sections it is obvious that the deposits of the Shchyrets section originated in deeper, more poorly oxygenated bottom waters. Foraminiferal assemblages in the Shchyrets section are dominated by Bulimina, Globocassidulina and Uvigerina, i.e., dysoxic indicators.

Aquatic palynomorph assemblages from the Anadoly section differ significantly from assemblages collected from the sections located in a similar position just above the Ratyn Limestone at Kudryntsi and Shchyrets (see Gedl and Peryt, 2011; Peryt et al., 2014 respectively). The main difference is lower diversity and a dominance of Polysphaeridium at Anadoly. At Kudryntsi, Polysphaeridium is subordinate, and it is lacking at Shchyrets. Dinoflagellate cysts at Kudryntsi and Shchyrets show a higher taxonomical diversity; particularly Spiniferites ramosus and Operculodinium, which are almost absent at Anadoly, and are frequent to very frequent in most of the Kudryntsi and Shchyrets samples. Offshore species like Impagidinium or Nematosphaeropsis, which are absent at Anadoly, occur (although rare) at Kudryntsi, and are relatively frequent at Shchyrets (16\% in topmost part of the section). All these features can be interpreted as reflecting more proximal, shallower and pre- 
sumably higher saline water conditions at Anadoly. Some similarities between the Anadoly and Kudryntsi assemblages are visible in the composition of the assemblage from the topmost sample $\mathrm{M}-19$, in particular regarding its taxonomical diversity and the presence of Pentadinium sp. This implies similar environmental conditions for the depositional setting of the Kudryntsi section and the topmost part of the Anadoly section. Shchyrets assemblages, with their highest taxonomical richness, lack of Polysphaeridium, and relatively frequent occurrence, suggest the most offshore sedimentary setting of all three analysed sections.

Another difference between Anadoly and the Kudryntsi and Shchyrets sites is reflected in different acritarch assemblages. Cold-water prasinophyceans (Cymatiosphaera spp.) are present at the base of the succession at Anadoly, but they are lacking at Kudryntsi and Shchyrets (see Gedl and Peryt, 2011; Peryt et al., 2014). Micrhystridium? sp. from the top of the Anadoly section may reflect warmer-water conditions (see Schreck et al., 2013: p. 55) in comparison to water temperature just after deposition of the Ratyn Limestone (i.e., the lowermost part of the Anadoly section). Nannobarbophora gedlii (ex Svenkodinium versteeghii, see Head, 2003), presumably a warm-water species (see Gedl, 1996; Schreck et al., 2013), is absent at Anadoly, but it was noted from the upper parts of the Kudryntsi and Shchyrets sections (Gedl and Peryt, 2011; Peryt et al., 2014); its occurrence can be correlated with the Micrhystridium? sp. occurrence at Anadoly, and reflects slightly warmer water conditions (Fig. 12).

Anadoly samples yielded rare bisaccate pollen grains (up to a few percent of the palynofacies; difficult to estimate their true proportion as partly they might be a recent contamination), which are usually common in Miocene strata of the Carpathian Foredeep (see e.g., Gedl, 1996, 1997, 1999). Their lack contrasts with their frequent occurrence in coeval strata at Kudryntsi and Shchyrets (Gedl and Peryt, 2011; Peryt et al., 2014).

Considerable differences between the Anadoly and, in particular, Kudryntsi sections remain enigmatic. The Anadoly section is characterized by the less diversified taxonomic composition of phytoplankton and sporadic occurrence of bisaccate pollen grains. Their structure favours transportation over hundreds of kilometres so if they occur in Kudryntsi, it is reasonable to expect them also in Anadoly. A necessary condition to preserve sporomorphs is low $\mathrm{pH}$ so the alkaline environment could result in a selective occurrence of dinocysts and the dominance of acritarchs that are characterized by an exceptionally resistant cell membrane as it is recorded in Anadoly. However, there is no proof for a pH shift towards alkalinity. On the other hand, the low frequency of bisaccate pollen grains in Anadoly may be caused by many factors, including palaeogeography (lack of emerged areas with coniferous tree vegetation) and hydrodynamics (water currents responsible for removal of these grains). The proximal, shallow-marine setting, as deduced from dinoflagellate cyst assemblages, suggests rather the latter option as an explanation for the rarity of pollen grains. More offshore settings at Kudryntsi and Shchyrets could be a place for accumulation of wind- or water-current transported bisaccate pollen grains (the so-called "Neves effect" of Chaloner and Muir, 1968).

Our palaeoenvironmental interpretations of the Anadoly section based on foraminifers and dinoflagellate cysts show some discrepancies (cf. Fig. 12) although the overall pictures are similar. Both groups show that during deposition of the lower part of the section studied shallow-marine conditions prevailed that subsequently were changes during the deposition of the middle part when the salinity was increasing as indicated by the phytoplankton record. This is clearly seen in samples M-16 and M-17 where Polysphaeridium predominates among the phytoplankton. In the uppermost part of the Anadoly section the return to normal marine salinity and the depth increase is recorded in both groups (Fig. 12).

A possible explanation of those discrepancies could be related to various ecological niches of both microfossil groups, as dinoflagellate cysts are planktonic and most of foraminifera from strata in question are benthic. However, planktonic forms also occur among foraminifera, particularly in the upper part of the studied section (above sample M-12; up to $40 \%$ in sample $\mathrm{M}-13)$ - in the same interval the dinoflagellate cyst record shows a high taxonomic impoverishment and dominance of Polysphaeridium and Cleistosphaeridium placacanthum (the former species is regarded as tolerant to increased salinity); hence, dinoflagellate cysts show hypersaline conditions (possibly associated with shallow, lagoonal waters) whereas foraminifers point to fully marine conditions in a gradually deepening basin. Such a discrepancy could be explained by the resedimentation of dinoflagellates from lagoonal environments into more offshore parts of the basin. In such a model the presence of offshore dinoflagellate cysts would be expected, which, however, are absent throughout most of the section (they appear in the topmost sample M-19). Another explanation implies a stratification in the water column of the basin at Anadoly leading to a hypersaline surface water layer inhabited by photosynthetic dinoflagellates, and deeper waters with normal salinity occupied by planktonic (middle part of the water column) and benthic (bottom waters) species. Theoretically, more saline, denser sea water, as a heavier one, should accumulate in the deeper basin parts. However, the excess of evaporation over precipitation may lead to a saltier surface water layer than the deeper waters, and such stratification can remain stable when the bottom waters are much cooler (i.e., denser). In our material, cold bottom water is suggested by the benthic foraminifers data. This phenomenon could be responsible for preventing the mixing of saltier surface waters and cold, normal saline sea water below the thermocline (Fig. 13). A similar model was proposed by Reichart et al. (2004) who described Polysphaeridium-dominated assemblages from offshore waters of the Arabian Sea. Frequent occurrence of this species, which is typical for hypersaline waters of the most proximal zones, i.a., in offshore waters of the Persian Gulf (see Bradford and Wall, 1984), was explained as a result of increased evaporation during warmer periods, leading to the appearance of a hypersaline surface water layer separated by a pycnocline from colder deeper waters. However, this model implies relatively deep, calm waters. In the case of Anadoly, the water depth was reconstructed as $20 \mathrm{~m}$ in the initial period, and over $50 \mathrm{~m}$ during subsequent phases. It remains a question if stratification could develop in such a shallow basin.

The above-presented models only hypothetically explain the discrepancies observed between foraminifera and dinoflagellate cysts studied from the same set of samples. There might be several other factors responsible for such a bimodal record, including climatic, ocean current distribution, local bottom morphology, bottom currents, trophic conditions, etc., all difficult to trace. Interestingly, comparison of our previous studies on palaeoenvironmental changes that preceded and followed the saline crisis in the Miocene of the Carpathian Foredeep show relatively coherent interpretations based on both fossil groups, as far only as they can be correlated (Peryt and Gedl, 2010; Gedl and Peryt, 2011; Peryt et al., 2014). This makes the discrepancies observed at Anadoly more enigmatic. However, similar differences were noted in the case of approximately coeval post-evaporitic strata of the Roztocze area in Poland. The Upper Badenian strata from that area yielded similar dinoflagellate cyst assemblages (composed of dominant Poly- 
Early stages of Late Badenian transgression at Anadoly
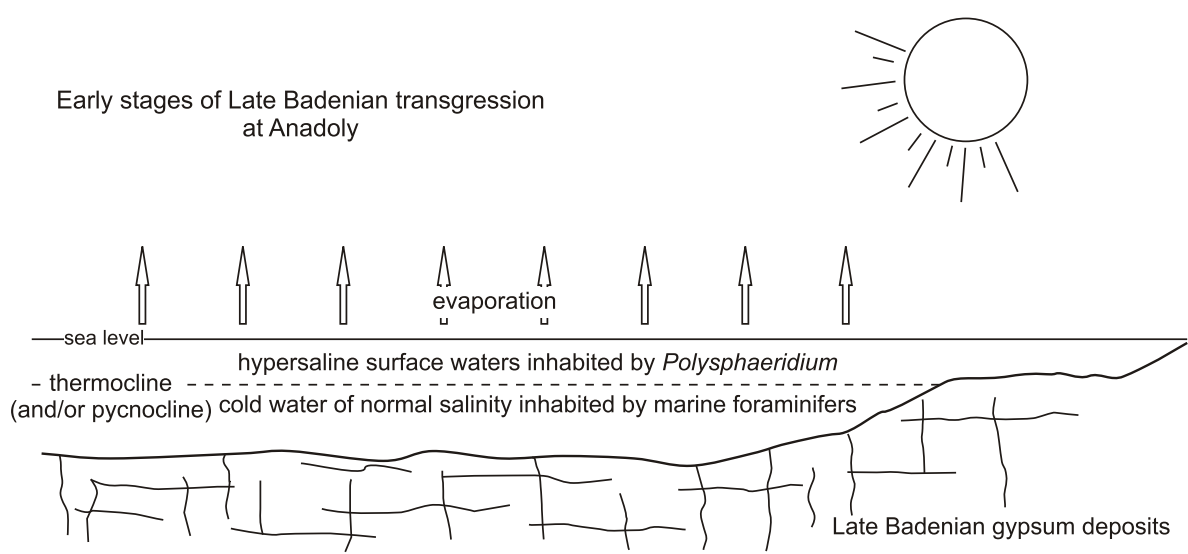

Fig. 13. A hypothetical model for environmental conditions during early stages of Late Badenian transgression at Anadoly

\begin{abstract}
Increased evaporation leads to a hypersaline surface water layer separated from colder deep waters inhabited by cold-water foraminifers below a thermocline/pycnocline. This warm, salty surface water layer forms a niche for Polysphaeridium - a genus that usually inhabits similar conditions but in shallow settings. Here, pycnocline could prevent non-motile cyst stages from sinking in deeper water zones
\end{abstract}

sphaeridium and associated by $C$. placacanthum and $L$. machaerophorum, and without other marine forms) interpreted as indicating increased salinity in a relatively shallow basin (Gedl, 2016). The same strata, similarly as in the case of Anadoly, yielded benthic foraminifers typical for relatively shallow waters of a marine basin, associated with infrequent planktonic species (Szczechura in Wysocka, 2002; Szczechura in Jasionowski et al., 2006). Moreover, the presence of stenohaline calcareous algae in the Upper Badenian of Roztocze (Wysocka, 2002) excludes hypersaline conditions, and some indications of high-energy environments (Jasionowski and Wysocka, 1997) exclude stratification.

Comparison of our data from three Ukrainian sections at Shchyrets, Kudryntsi and Anadoly shows the most offshore character of both foraminifers and dinoflagellate cysts at Shchyrets; Kudryntsi yielded assemblages that are typical for more proximal settings. Comparison of dinoflagellate cysts only shows the most nearshore and restricted (lagoonal) environment at Anadoly. Possibly, the Anadoly section might have accumulated in a nearshore lagoonal setting developed around an isolated area (island?).

\section{CONCLUSIONS}

1. The Upper Badenian Anadoly succession is composed of $5.3 \mathrm{~m}$ thick dark grey mudstones with limestone intercalations. 54 species of benthic (mostly calcareous) and 10 species of planktonic foraminifers (in the upper part of the succession) were identified. The foraminiferal record indicates deposition in a shallow subtidal environment (20 m depth) of normal marine salinity and temperate waters followed by gradual deepening of the basin to $>50 \mathrm{~m}$.

2. Analysis of foraminiferal assemblages indicate that bottom waters were highly oxygenated during the deposition of the lower and middle parts of the Anadoly sequence with the exception of the basal sample showing higher proportion of suboxic taxa. During the deposition of the upper part of the sequence oxygenation of bottom water was gradually decreasing, as expressed by a decrease of oxic species and an increase of dysoxic ones.

3. Assemblages II to VII from Kudryntsi roughly correspond to assemblages $A, B$ and $C$ from the Anadoly section, indicating similar environmental conditions at both sites at that time. The Shchyrets section in turn was deposited in a deeper sea with dysoxic bottom waters than the Kudryntsi and lower and middle parts of the Anadoly (Assemblages A, B and C) sections. Assemblage $E$ from the Anadoly section reflects probably similar environmental conditions to the ones present during the deposition of the Shchyrets succession.

4. Low amounts of palynological organic matter composed chiefly of most resistant black, opaque phytoclasts indicate limited terrestrial influx into the basin.

5. Analysis of dinoflagellate cysts suggests that the salinity of the surface waters increased throughout the deposition of the section. The most restricted conditions, presumably related to salinity fluctuations, took place during deposition of the middle part of the section, leading even to a temporary absence of dinoflagellate floras. Dinoflagellate cysts from the topmost part of the section indicate a gradual return of fully marine conditions in surface waters.

6. Dinoflagellate cysts from Anadoly resemble coeval assemblages from the Polish part of the Roztocze area by taxonomic impoverishment and the presence of dominant species tolerant for increased salinity.

7. Some discrepancies observed between foraminifers and dinoflagellate cysts studied from the same set of samples remain enigmatic. Similar differences were noted in a case of approximately coeval post-evaporitic strata of Roztocze (SE Poland).

Acknowledgements. The fieldwork was supported by research grant No. 6 P04D 00911 (Committee on Scientific Research) to T.M. Peryt, and the analyses by special grant No. Ukraina/193/2006 (Ministry of Science and Higher Education) to M. Kotarba. We thank M. Jasionowski and A.V. Poberezhskyy for their help in the field, and the journal reviewers: N. Hudáčková, M.A. Kaminski and B. Słodkowska for their helpful comments. 


\section{REFERENCES}

Andreyeva-Grigorovich, A.S., Kulchytsky, Y.O., Gruzman, A.D., Lozynyak, P.Y., Petrashkevich, M.I., Portnyagina, L.O., Ivanina, A.V., Smirnov, S.E., Trofimovich, N.A., Savitskaya, N.A., Shvareva, N.J., 1997. Regional stratigraphic scheme of Neogene formations of the Central Paratethys in the Ukraine. Geologica Carpathica, 48: 123-136.

Arslan, M., Kaminski, M.A., Tawabini, B.S., Ilyas, M., Frontalini, F., 2016. Benthic Foraminifera in sandy (siliciclastic) coastal sediments of the Arabian Gulf (Saudi Arabia): a technical report. Arabian Journal of Geosciences, 9: 285-291.

Babel, M., 2005. Event stratigraphy of the Badenian selenite evaporites (Middle Miocene) of the northern Carpathian Foredeep. Acta Geologica Polonica, 55: 9-29.

Bernhard, J.M., Sen Gupta, B., 1999. Foraminifera of oxygen-depleted environments. In: Modern Foraminifera (ed. B. Sen Gupta): 200-216. Kluwer Academic Publishers, Dordrecht.

Bicchi, E., Ferrero, E., Gonera, M., 2003. Palaeoclimatic interpretation based on Middle Miocene planktonic foraminifera. The Silesia Basin (Paratethys) and Monferrato (Tethys) records. Palaeogeography, Palaeoclimatology, Palaeoecology, 196: 265-303.

Bradford, M.R., Wall, D.A., 1984. The distribution of Recent organic-walled dinoflagellate cysts in the Persian Gulf, Gulf of Oman, and northwestern Arabian Sea. Palaeontographica, Abt. B, 192: 16-84.

Brinkhuis, H., 1994. Late Eocene to Early Oligocene dinoflagellate cysts from the Priabonian type-area (northeast Italy): biostratigraphy and palaeoenvironmental interpretation. Palaeogeography, Palaeoclimatology, Palaeoecology, 107: 121-163.

Chaloner, W.G., Muir, M., 1968. Spores and floras. In: Coal and Coal Bearing Strata (eds. D. Murchison and T.S. Westall): 127-146. Oliver and Boyd, Edinburgh.

Chendeş, C., Kaminski, M.A., Filipescu, S., Aksu, A.E., Yaşar, D., 2004. The response of modern benthic foraminiferal assemblages to water-mass properties along the southern shelf of the Marmara Sea. Acta Palaeontologica Romaniae, 4: 69-80.

Cicha, I., Rögl, F., Rupp, C., Čtyroká, J., 1998. Oligocene-Miocene Foraminifera of the Central Paratethys. Kramer, Frankfurt am Main.

Culver, S., 1988. New foraminiferal depth zonation of the northwestern Gulf of Mexico. Palaios, 3: 69-85.

Dale, B., 1996. Dinoflagellate cyst ecology: modelling and geological applications. In: Palynology: Principles and Applications, 3 (eds. J. Jansonius and D.C. McGregor): 1249-1275. American Association of Stratigraphic Palynologists Foundation, Dallas, Texas.

De Schepper, S., Head, M.J., 2014. New late Cenozoic acritarchs: evolution, palaeoecology and correlation potential in high latitude oceans. Journal of Systematic Palaeontology, 12: 493-519.

de Leeuw, A., Bukowski, K., Krijgsman, W., Kuiper, K.F., 2010. Age of the Badenian salinity crisis; impact of Miocene climate variability on the circum-Mediterranean region. Geology, 38: 715-718.

de Leeuw, A., Filipescu, S., Ma enco, L., Krijgsman, W., Kuiper, K., Stoica, M., 2013. Paleomagnetic and chronostratigraphic constraints on the Middle to Late Miocene evolution of the Transylvanian Basin (Romania): implications for Central Paratethys stratigraphy and emplacement of the Tisza-Dacia plate. Global and Planetary Change, 103: 82-98.

Edwards, L.E., Andrle, V.A.S., 1992. Distribution of selected dinoflagellate cysts in modern marine sediments. In: Neogene and Quaternary Dinoflagellate Cysts and Acritarchs (eds. M.J. Head and J.H. Wrenn): 259-288. American Association of Stratigraphic Palynologists Foundation.

Ellegaard, M., 2000. Variations in dinoflagellate cyst morphology under conditions of changing salinity during the last 2000 years in the Limfjord, Denmark. Review of Palaeobotany and Palynology, 109: 65-81.

Fensome, R.A., MacRae, R.A., Williams, G.L., 2008. DINOFLAJ2, Version 1. American Association of Stratigraphic Palynologists, Data Series, 1: Available from: http://dinoflaj.smu.ca/wiki/Main_Page.

Gebhardt, H., 1999. Middle to Upper Miocene benthonic foraminiferal palaeoecology of the Tap Marls (Alicante Province, SE
Spain) and its palaeoceanographic implications. Palaeogeography, Palaeoclimatology, Palaeoecology, 145: 141-156.

Gedl, P., 1996. Middle Miocene dinoflagellate cysts from the Korytnica clays (Góry Świętokrzyskie Mountains, Poland). Annales Societatis Geologorum Poloniae, 66: 191-218.

Gedl, P., 1997. Palynofacies of the Miocene deposits in the Gliwice area (Upper Silesia, Poland). Bulletin of the Polish Academy of Sciences, Earth Sciences, 45: 191-201.

Gedl, P., 1999. Palaeoenvironmental and sedimentological interpretations of the palynofacies analysis of the Miocene deposits from the Jamnica S-119 borehole (Carpathian Foredeep, Poland). Geological Quarterly, 43 (4): 479-492.

Gedl, P., 2016. Dinoflagellate cysts and palynofacies from the upper Badenian (Middle Miocene) of the Roztocze area at Józefów and elebsko (Carpathian Foredeep Basin, Poland): palaeoenvironmental implications. Annales Societatis Geologorum Poloniae, 86, doi: http://dx.doi.org/10.14241/asgp.2016.010

Gedl, P., Peryt, D., 2011. Dinoflagellate cyst, palynofacies and foraminiferal records of environmental changes related to the Late Badenian (Middle Miocene) transgression at Kudryntsi (western Ukraine). Annales Societatis Geologorum Poloniae, 81: 331-349.

Gozhyk, P., Semenenko, V., Andreeva-Grigorovich, A., Maslun, V., 2015. The correlation of the Neogene of Central and Eastern Paratethys segments of Ukraine with the International Stratigraphic Chart based on planktonic microfossils. Geologica Carpathica, 66: 235-244.

Harland, R., 1983. Distribution maps of recent dinoflagellate cysts in bottom sediments from the North Atlantic Ocean and adjacent seas. Palaeontology, 26: 321-387.

Hayward, B.W., 2014. "Monospecific" and near-monospecific benthic foraminiferal faunas, New Zealand. Journal of Foraminiferal Research, 44: 300-315.

Hayward, B.W., Hollis, C.J., Grenfell, H.R., 1997. Recent Elphidiidae (Foraminiferida) of the south-west Pacific and fossil Elphidiidae of New Zealand. Institute of Geological and Nuclear Sciences Monograph, 16 (New Zealand Geological Survey). Paleontological Bulletin, 72: 1-166.

Hayward, B.W., Grenfell, H.R., Reid, C., 2010. Foraminiferal associations in Wanganui Bight and Queen Charlotte Sound, New Zealand. New Zealand Journal of Marine and Freshwater Research, 31: 337-365.

Head, M.J., 2003. Neogene occurrences of the marine acritarch genus Nannobarbophora Habib and Knapp, 1982 emend, and the new species N. gedlii. Journal of Paleontology, 77: 382-385.

Head, M.J., Norris, G., Mudie, P., 1989. New species of dinocysts and a new species of acritarch from the upper Miocene and lowermost Pliocene, ODP Leg 105, Site 646, Labrador Sea. Proceedings of the Ocean Drilling Program, Scientific Results, 105: 453-466.

Hemleben, C., Spindler, M., Anderson, O.R., 1989. Modern Planktonic Foraminifera. Springer, New York.

Hohenegger, J., 2005. Estimation of environmental paleogradient values based on presence/absence data: a case study using benthic foraminifera for paleodepth estimation. Palaeogeography, Palaeoclimatology, Palaeoecology, 217: 115-130.

Hohenegger, J., Ćorić, S., Wagreich, M., 2014. Timing of the Middle Miocene Badenian Stage of the Central Paratethys. Geologica Carpathica, 65: 55-66.

Holcová, K., Brzobohatý, R., Kopecká, J., Nehyba, S., 2015. Reconstruction of the unusual Middle Miocene (Badenian) palaeoenvironment of the Carpathian Foredeep (Lomnice/Tišnov denudational relict, Czech Republic). Geological Quarterly, 59 (4): 654-678.

laccarino, S.M., Premoli Silva, I., Biolzi, M., Foresi, L.M., Lirer, F., Turco, E., Petrizzo, M.R., 2007. Practical Manual of Neogene Planktonic Foraminifera. In: International School on Planktonic Foraminifera (6th course) (eds. M. Biolzi et al.). Tipografia Pontefelicino, Perugia.

Jasionowski, M., Wysocka, A., 1997. Middle Miocene algae and microbialites of Roztocze (south-eastern Poland). In: 3rd Re- 
gional Symposium of International Fossil Algae Association and 3rd International Meeting of IGCP 380, Guidebook and Abstracts. Institute of Geological Sciences, Jagiellonian University, Kraków: 23-31.

Jasionowski, M., Wysocka, A., Studencka, B., 2006. Stop IV Kamieniołom w elebsku (in Polish). In: Przebieg i zmienność sedymentacji w basenach przedgórskich, Zwierzyniec, 20-23.06.2006 r. II Polska Konferencja Sedymentologiczna POKOS2 (eds. A. Wysocka and M. Jasionowski): 25-27. Instytut Geologii Podstawowej, Wydział Geologii UW, Warszawa.

Jorissen, F.J., Barmavidjaja, D.M., Puskaric, S., van der Zwaan, G.J., 1992. Vertical distribution of benthic foraminifera in the northern Adriatic Sea: the relation with the organic flux. Marine Micropaleontology, 19: 131-146.

Jorissen, F.J., de Stigter, H.C., Widmark, J.G.V., 1995. A conceptual model explaining benthic foraminiferal microhabitats. Marine Micropaleontology, 26: 3-15.

Kaiho, K., 1994. Benthic foraminiferal dissolved-oxygen index and dissolved-oxygen levels in the modern ocean. Geology, 22: 719-722.

Kaminski, M.A., 2012. Calibration of the Benthic Foraminiferal Oxygen Index in the Marmara Sea. Geological Quarterly, 56 (4): 757-764.

Koltun, V.I., Roskosh, Y.T., Sen'kovskyy, Y.M., Yasins'ka, A.A., 1972. Lithogenesis of sulphur deposits of the Pre-Carpathians (in Ukrainian). Kiev, Naukova Dumka.

Kouwenhoven, T.J., van der Zwaan, G.J., 2006. A reconstruction of late Miocene Mediterranean circulation patterns using benthic foraminifera. Palaeogeography, Palaeoclimatology, Palaeoecology, 238: 373-385

Kováč, M., Andreyeva-Grigorovich, A., Bajraktarević, Z., Brzobohatý, R., Filipescu, S., Fodor, L., Harzhauser, M., Nagymarosy, A., Oszczypko, N., Pavelić, D., Rögl, F., Saftić, B., Sliva, L'., Studencka, B., 2007. Badenian evolution of the Central Paratethys Sea: paleogeography, climate and eustatic sea-level changes. Geologica Carpathica, 58: 579-606.

Kováčová, P., Hudáčková, N., 2009. Late Badenian foraminifers from the Vienna Basin (Central Paratethys): stable isotope study and paleoecological implications. Geologica Carpathica, 60: 59-70.

Kováčová, P., Emanuel, L., Hudáčková, N., Renard, M., 2009. Central Paratethys paleoenvironment during the Badenian (Middle Miocene): evidence from foraminifera and stable isotope $\left(\delta^{13} \mathrm{C}\right.$ and $\left.\delta^{18} \mathrm{O}\right)$ study in the Vienna Basin (Slovakia). International Journal of Earth Sciences, 98: 1109-1127.

Köthe, A., 1990. Paleogene dinoflagellates from northwest Germany. Geologisches Jahrbuch, A118: 1-111.

Kudrin, L.N., 1966. Stratigraphy, facies and ecological analysis of fauna of the Paleogene and Neogene deposits of the Forecarpathians (in Russian). Lvov, Izd. Lvovsk. Univ.

Langer, M.R., 1993. Epiphytic foraminifera. Marine Micropaleontology, 20: 235-265.

Loeblich, A.R. Jr., Tappan, H., 1987. Foraminiferal Genera and their Classification. Van Nostrand Reinhold, New York.

Lutze, G.F., Coulbourn, W.T., 1984. Recent benthic foraminifera from the continental margin of northwest Africa: community structure and distribution. Marine Micropaleontology, 8: 361-401.

Lutze, G.F., Thiel, H., 1989. Epibenthic foraminifera from elevated microhabitats; Cibicidoides wuellerstorfi and Planulina ariminensis. Journal of Foraminiferal Research, 19: 153-158.

Łomnicki, A.M., 1897. Geological Atlas of Galicia (in Polish), 10 (2). Kraków, Polska Akademia Umiejętności.

Marret, F., Zonneveld, K.A.F., 2003. Atlas of modern organic-walled dinoflagellate cyst distribution. Review of Palaeobotany and Palynology, 125: 1-200.

Morzadec-Kerfourn, M.-T., 1977. Les kystes de dinoflagellés dans les sédiments récents le long des côtes Bretonnes. Revue de Micropaléontologie, 20: 157-166.

Murray, J.W., 1976. Comparative studies of living and dead benthic foraminiferal distributions. In: Foraminifera (eds. R.H. Hedley and C.G. Adams), 2: 45-109. Academic Press, London.

Murray, J.W., 1991. Ecology and Palaeoecology of Benthic Foraminifera. Longman, Avon.

Murray, J.W., 2006. Ecology and Applications of Benthic Foraminifera. Cambridge University Press, Cambridge.
Oszczypko, N., Krzywiec, P., Popadyuk, I., Peryt, T., 2006. Carpathian Foredeep Basin (Poland and Ukraine): its sedimentary, structural, and geodynamic evolution. AAPG Memoir, 84: 293-350.

Peryt, D., 2013. Foraminiferal record of the Middle Miocene climate transition prior to the Badenian salinity crisis in the Polish Carpathian Foredeep Basin (Central Paratethys). Geological Quarterly, 57 (1): 141-164.

Peryt, D., Gedl, P., 2010. Palaeoenvironmental changes preceding the Middle Miocene Badenian salinity crisis in the northern Polish Carpathian Foredeep Basin (Borków quarry) inferred from foraminifers and dinoflagellate cysts. Geological Quarterly, 54 (4): 487-508.

Peryt, D., Peryt, T.M., 2009. Environmental changes in the declining Middle Miocene Badenian evaporite basin of the Ukrainian Carpathian Foredeep (Kudryntsi section). Geologica Carpathica, 60: 505-517.

Peryt, D., Gedl, P., Peryt, T.M., 2014. Foraminiferal and palynological records of the Late Badenian transgression in Podolia (Shchyrets near Lviv, western Ukraine). Geological Quarterly, 58 (3): 465-484.

Peryt, T.M., 1996. Sedimentology of Badenian (middle Miocene) gypsum in eastern Galicia, Podolia and Bukovina (West Ukraine). Sedimentology, 43: 571-588.

Peryt, T.M., 2006. The beginning, development and termination of the Middle Miocene Badenian salinity crisis in Central Paratethys. Sedimentary Geology, 188-189: 379-396.

Peryt, T.M., Peryt, D., 1994. Badenian (Middle Miocene) Ratyn Limestone in western Ukraine and northern Moldavia: microfacies, calcareous nannoplankton and isotope geochemistry. Bulletin of the Polish Academy of Sciences, Earth Sciences, 42: $127-136$.

Peryt, T.M., Peryt, D., Jasionowski, M., Poberezhskyy, A.V., Durakiewicz, T., 2004. Post-evaporitic restricted deposition in the Middle Miocene Chokrakian-Karaganian of East Crimea (Ukraine). Sedimentary Geology, 170: 21-36.

Peryt, T.M., Durakiewicz, T., Peryt, D., Poberezhskyy, A., 2012. Carbon and oxygen isotopic composition of the Middle Miocene Badenian gypsum-associated limestones of West Ukraine. Geologica Acta, 10: 319-332.

Petrichenko, O.I., Peryt, T.M., Poberegsky, A.V., 1997. Pecularities of gypsum sedimentation in the Middle Miocene Badenian evaporite basin of Carpathian Foredeep. Slovak Geological Magazine, 3: 91-104.

Quaijtaal, W., Mertens, K.N., Louwye, S., 2015. Some new acritarch species from the lower and middle Miocene of the Porcupine Basin, North Atlantic Ocean: biostratigraphy and palaeoecology. Palynology, 39: 37-55.

Reichart, G.-J., Brinkhuis, H., Huiskamp, F., Zachariasse, W.J., 2004. Hyper-stratification following glacial overturning events in the northern Arabian Sea. Paleoceanography, 19: PA2013, doi: 10.1029/2003PA000900

Rögl, F., 1998. Palaeogeogeographic considerations for the Mediterranean and Paratethys sea ways (Oligocene to Miocene). Annalen des Naturhistorischen Museums in Wien, 99 (A): 279-310.

Schreck, M., Meheust, M., Stein, R., Matthiessen, J., 2013. Response of marine palynomorphs to Neogene climate cooling in the Iceland Sea (ODP Hole 907A). Marine Micropaleontology, 101: 49-67.

Sidorenko, M.D., 1904. Description of some minerals and rocks from gypsum deposits of the Khotyn district, Bessarabia province (in Russian). Zapiski Novorosiyskogo Obshchestva Ispytateley Prirody, 27: 1-109.

Sjoerdsma, P.G., van der Zwaan, G.J., 1992. Simulating the effect of changing oceanic flux and oxygen content on the distribution of benthic foraminifers. Marine Micropaleontology, 19: 163-180.

Sluijs, A., Pross, J., Brinkhuis, H., 2005. From greenhouse to icehouse; organic-walled dinoflagellate cysts as paleoenvironmental indicators in the Paleogene. Earth-Science Reviews, 68: 281-315.

Spezzaferri, S., Corić, C., Hohenegger, J., 2002. Basin-scale paleobiogeography and paleoecology: an example from Karpatian (Latest Burdigalian) benthic and planktonic foraminifera and calcareous nannofossils from the Central Paratethys. Geobios, 35: 241-256.

Studencka, B., Prysyazhnyuk, V.A., Ljul'eva, S.A., 2012. First record of the bivalve species Parvamussium fenestratum (Forbes, 
1844) from the Middle Miocene of the Paratethys. Geological Quarterly, 56 (3): 513-528.

Szczechura, J., 1982. Middle Miocene foraminiferal biochronology and ecology of SE Poland. Acta Palaeontologica Polonica, 27: 3-44.

Szczechura, J., 1984. Morphologic variability in the Globigerinoides-Orbulina group from the Middle Miocene of Central Paratethys. Acta Palaeontologica Polonica, 29: 3-27.

Szczechura, J., 2000. Age and evolution of depositional environments of the supra-evaporitic deposits in the northern, marginal part of the Carpathian Foredeep: micropalaeontological evidence. Geological Quarterly, 44 (1): 81-100.

Teisseyre, W., 1900. Geological Atlas of Galicia, 8 (in Polish). Wydawnictwo Komisyi Fizjograficznej Akademii Umiejętności, Kraków.

Thomas, E., 1980. Details of Uvigerina development in the Cretan Mio-Pliocene. Utrecht Micropaleontological Bulletins, 23: 1-167.

Van der Zwaan, G.J., 1982. Paleoecology of late Miocene Mediterranean Foraminifera. Utrecht Micropaleontological Bulletins, 25: 1-202.

Van der Zwaan, G.J., 1983. Quantitative analysis and the reconstruction of benthic foraminiferal communities. Reconstruction of marine paleoenvironments. Utrecht Micropaleontological Bulletins, 30: 49-69.

Van der Zwaan, G.J., Duijnstee, I.A.P., den Dulk, M., Ernst, S.R., Jannink, N.T., Kouwenhoven, T.J., 1999. Benthic foraminifers: proxies or problems? A review of paleoecological concepts. Earth-Science Reviews, 46: 213-236.
Van Hinsbergen, D.J.J., Kouwenhoven, T.J., van der Zwaan, G.J., 2005. Paleobathymetry in the backstripping proce dure: correction for oxygenation effects on depth estimates. Palaeogeography, Palaeoclimatology, Palaeoecology, 221: 245-265.

Verhallen, P., 1991. Late Pliocene to early Pleistocene Mediterranean mud-dwelling foraminifera; influence of a changing environment on community structure and evolution. Utrecht Micropaleontological Bulletins, 40: 1-219.

Vjalov, O.S., Havura, S.P., Danysh, V.V., Leshchukh, P.I., Ponomariova, L.D., Romaniv, A.M., Tsarnenko, P.N., Tsizh, I.T., 1981. History of Geologic Development of the Ukrainian Carpathians (in Russian). Kiev, Naukova Dumka.

Wall, D., Dale, B., 1973. Paleosalinity relationships of dinoflagellates in the Late Quaternary of the Black Sea - a summary. Geoscience and Man, 7: 95-102.

Wall, D., Dale, B., Lohmann, G.P., Smith, W.K., 1977. The environmental and climatic distribution of dinoflagellate cysts in modern marine sediments from regions in the north and south Atlantic Oceans and adjacent seas. Marine Micropalaeontology, 2: 121-200.

Williams, G.L., 1977. Dinocysts: their paleontology, biostratigraphy and paleoecology. In: Oceanic Micropalaeontology (ed. A.T.S. Ramsay): 1231-1325. Academic Press, London.

Wysocka, A., 2002. Clastic Badenian deposits and sedimentary environments of the Roztocze Hills across the Polish-Ukrainian border. Acta Geologica Polonica, 52: 535-561.

\title{
APPENDIX
}

Faunal reference list of the identified foraminifers and dinoflagellate cysts. Taxonomy of the Foraminifers follows Cicha et al. (1998) and laccarino et al. (2007); their descriptions and representative illustrations can be found in those publications. Dinoflagellate cyst full taxonomic citations are given in Fensome et al. (2008)

\author{
FORAMINIFERA
}

\section{Benthic}

Bolivina dilatata Reuss, 1850 (Fig. 6Q)

Bolivina maxima Cicha and Zapletalova, 1963 (Fig. 6R)

Bolivina sp.

Bulimina aculeata d'Orbigny, 1846 (Fig. 6M-P)

Bulimina elongata d'Orbigny, 1846

Bulimina insignis Łuczkowska, 1953 (Fig. 6J-L)

Bulimina sp.

Cibicidoides austriacus (d'Orbigny, 1846)

Cibicidoides pseudoungerianus (Cushman, 1922) (Fig. 5R, S)

Cibicidoides ungerianus (d'Orbigny, 1846)

Elphidium advenum (Cushman, 1922) (Fig. 5M)

Elphidium crispum (Linné, 1758) (Fig. 5G)

Elphidium fichtelianum (d'Orbigny, 1846) (Fig. 5A, H)

Elphidium joukovi Serova, 1955 (Fig. 5B)

Elphidium macellum (Fichtel et Moll, 1798) (Fig. 5C)

Elphidium sp.

Eponides repandus (Fichtel et Moll, 1798)

Florilus sp.

Fursenkoina acuta (d'Orbigny, 1846)

Glandulina ovula d'Orbigny, 1846

Guttulina communis d'Orbigny, 1826

Globocassidulina oblonga (Reuss, 1850) (Fig. 6S, T)

Globulina sp.

Guttulina sp.

Hanzawaia boueana (d'Orbigny, 1846) (Fig. 6X, Y)

Heterolepa dutemplei (d'Orbigny, 1846) (Fig. 6Cc, Dd)

Hoeglundina elegans (d'Orbigny, 1826) (Fig. 6Aa, Bb)

Lenticulina sp. 
Lobatula lobatula (Walker et Jacob, 1798) (Fig. 5K)

Melonis pompilioides (Fichtel et Moll, 1798) (Fig. 5T)

Neoconorbina schreibersi (d'Orbigny, 1846) (Fig. 5Q)

Nonion commune (d'Orbigny, 1826)

Nonion tumidulus Pishvanova, 1960

Porosononion granosum (d'Orbigny, 1826) (Fig. 5L)

Porosononion martkobi (Bogdanowicz, 1947) (Fig. 5N)

Pseudotriloculina consobrina (d'Orbigny, 1846) (Fig. 5F)

Pullenia bulloides (d'Orbigny, 1826) (Fig. 6Ff)

Pullenia miocenica Kleinpell, 1938 (Fig. 6Ee)

Pyrgo sp.

Quinqueloculina sp. (Fig. 5D, E)

Reussella spinulosa (Reuss, 1850)

Rosalina obtusa (d'Orbigny, 1846) (Fig. 5P)

Semivulvulina sp. (Fig. 6W)

Sigmoilinita tenuis (Czjzek, 1848)

Siphotextularia concava (Karrer,1868) (Fig. 6Z)

Sphaeroidina bulloides d'Orbigny, 1826 (Fig. 6U, V)

Triloculina gibba (d'Orbigny, 1826)

Triloculina sp.

Uvigerina aculeata d'Orbigny, 1846 (Fig. 6A, B)

Uvigerina brunnensis (Karrer, 1877) (Fig. 6H, I)

Uvigerina semiornata (d'Orbigny, 1846) (Fig. 6C-G)

Uvigerina sp.

Valvulineria bradyana (Fornasini, 1900)

Virgulinopsis sp.

\section{Planktonic}

Globigerina bulloides d'Orbigny, 1826 (Fig. 4B, H)

Globigerina falconensis Blow, 1959 (Fig. 4G)

Globigerina praebulloides Blow, 1959 (Fig. 4E)

Globigerina tarchanensis Subbotina et Chutzieva, 1950 (Fig. 4F)

Globigerina sp.

Globigerinita uvula (Ehrenberg, 1862) (Fig. 4C)

Globigerinoides quadrilobatus (d'Orbigny, 1846) (Fig. 4I, L, O)

Globigerinoides trilobus (Reuss, 1850) (Fig. 4J, K, N)

Globigerinoides sp. (Fig. 4M)

Tenuitellinata juvenilis (Bolli, 1957) (Fig. 4A, D)

\section{DINOFLAGELLATE CYSTS}

Cleistosphaeridium placacanthum (Deflandre et Cookson, 1955) Eaton et al., 2001 (Fig. 11E-G)

Cleistosphaeridium cf. placacanthum (Deflandre et Cookson, 1955) Eaton et al., 2001 (Fig. 11M, N)

Dapsilidinium pseudocolligerum (Stover, 1977) Bujak et al., 1980 (Fig. 110)

Dapsilidinium sp. (Fig. 11H, I)

Hystrichokolpoma sp.

Lingulodinium machaerophorum (Deflandre et Cookson, 1955) Wall, 1967 (Fig. 11A-D)

Operculodinium centrocarpum (Deflandre and Cookson, 1955) Wall, 1967

Operculodinium sp.

Pentadinium sp. (Fig. 11J-L, P)

Polysphaeridium subtile Davey et Williams, 1966 (Fig. 10C-O, S)

Polysphaeridium zoharyi (Rossignol, 1962) Bujak et al., 1980 (Fig. 10A, B, P-R)

Spiniferites pseudofurcatus (Klumpp, 1953) Sarjeant, 1970 (Fig. 11Q)

Spiniferites ramosus (Ehrenberg, 1838) Mantell, 1854

PRASINOPHYCEANS AND ACRITARCHS

Cymatiosphaera sp. A (Fig. 12A-C, F-H, X)

Cymatiosphaera sp. B (Fig. 12K-S, V, W)

Cymatiosphaera sp. C (Fig. 12D-E, I, J)

Cymatiosphaera sp. (Fig. 12T, U)

Micrhystridium? sp. (Fig. 12Y-Z3) 